\title{
Re-oxygenation after anoxia induces brain cell death and memory loss in the anoxia-tolerant crucian carp
}

\author{
Sjannie Lefevre ${ }^{1, \neq \ddagger}$, Jonathan A. W. Stecyk ${ }^{1, *}$, May-Kristin Torp ${ }^{1, \ddagger}$, Lisa Y. Løvold ${ }^{1, \S}$, Christina Sørensen ${ }^{1, \pi}$, Ida \\ B. Johansen ${ }^{1, * *}$, Kåre-Olav Stensløkken ${ }^{1, \pm}$, Christine S. Couturier ${ }^{1, *}$, Katherine A. Sloman ${ }^{2}$ and Göran E. Nilsson ${ }^{1}$
}

\begin{abstract}
Crucian carp (Carassius carassius) survive without oxygen for several months, but it is unknown whether they are able to protect themselves from cell death normally caused by the absence, and particularly return, of oxygen. Here, we quantified cell death in brain tissue from crucian carp exposed to anoxia and re-oxygenation using the terminal deoxy-nucleotidyl transferase dUTP nick-end labelling (TUNEL) assay, and cell proliferation by immunohistochemical staining for proliferating cell nuclear antigen (PCNA) as well as PCNA mRNA expression. We also measured mRNA and protein expression of the apoptosis executer protease caspase 3 , in laboratory fish exposed to anoxia and re-oxygenation and fish exposed to seasonal anoxia and reoxygenation in their natural habitat over the year. Finally, a behavioural experiment was used to assess the ability to learn and remember how to navigate in a maze to find food, before and after exposure to anoxia and re-oxygenation. The number of TUNEL-positive cells in the telencephalon increased after 1 day of re-oxygenation following 7 days of anoxia, indicating increased cell death. However, there were no consistent changes in whole-brain expression of caspase 3 in either laboratory-exposed or naturally exposed fish, indicating that cell death might occur via caspase-independent pathways or necrosis. Re-oxygenated crucian carp appeared to have lost the memory of how to navigate in a maze (learnt prior to anoxia exposure), while the ability to learn remained intact. PCNA mRNA was elevated after re-oxygenation, indicating increased neurogenesis. We conclude that anoxia tolerance involves not only protection from damage but also repair after re-oxygenation.
\end{abstract}

KEY WORDS: Fish, Caspase 3, Cell proliferation, Gene expression, Learning

\section{INTRODUCTION}

The ability of the crucian carp (Carassius carassius) to survive anoxia for several months, during overwintering in ice-covered lakes of northern Europe, is well established (e.g. Vornanen et al.,

\footnotetext{
${ }^{1}$ Department of Biosciences, Faculty of Mathematics and Natural Sciences, University of Oslo, 0371 Oslo, Norway. ${ }^{2}$ Institute of Biomedical and Environmental Health Research, School of Science and Sport, University of the West of Scotland, PA1 2BE, UK

*Present address: Department of Biological Sciences, University of Alaska Anchorage, AK, USA. łPresent address: Institute of Basic Medical Sciences, Faculty of Medicine, University of Oslo, Norway. §Present address: Department of Pathology, Oslo University Hospital, Norway. "Present address: Centre for Neuroscience, University of Copenhagen, Denmark. **Present address: Department of Food Safety and Infection Biology, Norwegian University of Life Science, Norway.

‡¥Author for correspondence (sjannie.lefevre@imbv.uio.no)

D S.L., 0000-0003-0865-0561
}

Received 1 July 2017; Accepted 1 September 2017
2009). This fish species has therefore been studied intensely, and its survival strategy has been shown to include several elements. Crucian carp can maintain anaerobic adenosine triphosphate (ATP) production for much longer periods than other vertebrates because of the build-up of exceptionally large tissue glycogen stores, primarily in the liver, in the summer and autumn (Vornanen et al., 2009, 2011), and by entering a hypo-metabolic state during anoxia exposure (e.g. Nilsson, 1992, 2001). In addition, crucian carp produce ethanol as the major end-product of glycolysis (Johnston and Bernard, 1983; Fagernes et al., 2017). The release of ethanol into the water circumvents the accumulation of anaerobic endproducts, i.e. lactate and protons, which severely disturb acid-base balance in animals deprived of oxygen, as observed in the closely related common carp (Cyprinus carpio; Johnston and Bernard, 1983). Lastly, the crucian carp heart can maintain cardiac output without any oxygen (Stecyk et al., 2004), making it possible for the fish to maintain blood circulation and thereby activity (Nilsson, 2001; Nilsson and Lutz, 2004), while allowing for a sufficient release of ethanol over the gills (Stecyk et al., 2004; Farrell and Stecyk, 2007), thus preventing intoxication.

In most other vertebrates, brain ATP levels plummet within minutes of anoxia exposure, leading to a cessation of ion pumping, followed by a general depolarization of cells and loss of ion homeostasis, eventually resulting in cell death through necrosis (premature cell death) or apoptosis (programmed cell death) (Lipton, 1999). It has recently become clear that the traditional view of necrosis as a single disorderly process is oversimplified, and the term 'regulated necrosis' has been proposed to describe the increasing network of non-apoptotic yet controlled cell-death pathways (e.g. Berghe et al., 2014; Linkermann and Green, 2014). Regardless, necrotic cells can have fatal consequences for neighbouring tissues because they induce tissue inflammation (e.g. Proskuryakov et al., 2003), whereas in apoptosis the tissue constituents are processed in an orderly fashion and inflammation is avoided (see reviews by Elmore, 2007; Campo, 2009). Although apoptosis is a controlled process, it can be just as devastating as necrosis because it can be caused by relatively brief periods of anoxia and result in progressive cell death for days after an anoxic insult has ended (Lutz et al., 2003). Apoptosis caused by hypoxia, anoxia and other cellular stressors is primarily initiated in the mitochondria through a process referred to as the intrinsic pathway (Elmore, 2007). Specifically, the ATP deficit resulting from hypoxia and anoxia causes depolarization of the mitochondrial membrane and $\mathrm{Ca}^{2+}$ overload, and, subsequently, pores form in the inner and outer mitochondrial membranes through which so-called death factors, such as cytochrome $c$ and apoptosis-inducing factor (AIF), are released. Many forms of apoptosis are dependent on a special group of proteases (i.e. enzymes targeting other proteins) known as caspases, which are activated by, for example, cytochrome $c$ (Green and Reed, 1998; David et al., 2009). The 


\begin{tabular}{|c|c|}
\hline \multicolumn{2}{|c|}{ List of abbreviations } \\
\hline AIF & apoptosis inducing factor \\
\hline ATP & adenosine triphosphate \\
\hline casp3a & caspase $3 a$ \\
\hline casp3b & caspase $3 b$ \\
\hline $\mathrm{Cl}$ & confidence interval \\
\hline DAB & 3,3'-diaminobenzidine \\
\hline HRP & horseradish peroxidase \\
\hline IPTG & isopropyl $\beta$-D-1-thiogalactopyranoside \\
\hline PBS & phosphate-buffered saline \\
\hline PCNA & proliferating cell nuclear antigen \\
\hline qPCR & quantitative real-time PCR \\
\hline ROS & reactive oxygen species \\
\hline TBST & Tris-buffered saline Tween 20 \\
\hline TdT & terminal deoxynucleotidyl transferase \\
\hline TUNEL & terminal deoxynucleotidyl transferase dUTP nick-end labelling \\
\hline
\end{tabular}

executer caspases 3 and 9 have been directly linked to apoptosis in human cells induced by anoxia (Santore et al., 2002) and hypoxia/ re-oxygenation (Ho et al., 2006). Additionally, cell death can be induced shortly after re-oxygenation as a result of the oxidative damage to proteins and DNA caused by an increased production of reactive oxygen species (ROS). Indeed, increased ROS production and apoptosis, as well as regulated necrosis, have been linked to hypoxia and ischaemia-reperfusion injuries (Neumar, 2000; White et al., 2000; Zhao et al., 2015), for example in rat brain (Zhu et al., 2003) and human (Nohl et al., 1993) and mice (Zhang et al., 2016) cardiomyocytes. If cell death occurs during hypoxia/anoxia or following re-oxygenation, regardless of whether this is through apoptosis or necrosis, it is characterized in the later stages by the degradation of DNA. This feature makes it possible to detect cell death using the terminal deoxynucleotidyl transferase dUTP nickend labelling (TUNEL) assay (Gavrieli et al., 1992; Ansari et al., 1993; Charriaut-Marlangue and Ben-Ari, 1995; Grasl-Kraupp et al., 1995).

Unlike mammals and most other vertebrates, the crucian carp is able to maintain sufficient ATP levels during anoxia to meet the slightly lowered demand (Johansson and Nilsson, 1995; Nilsson, 2001). It has therefore generally been presumed that the fish avoids anoxia-induced cell death. While no studies have been conducted on crucian carp, there are studies suggesting that some anoxia-tolerant freshwater turtles (Trachemys sp. and Chrysemys sp.) are actually able to prevent cell death during anoxia and re-oxygenation (Kesaraju et al., 2009; Nayak et al., 2010; Pamenter, 2014). These animals exhibit an extreme suppression of ATP demand through decreased neuronal activity ('spike arrest'; Perez-Pinzon et al., 1992; Fernandes et al., 1997), which is mediated through increased GABAergic activity (Nilsson and Lutz, 1993; Pamenter et al., 2011), as well as channel arrest mediated through suppressed glutamatergic activity (Buck and Bickler, 1995, 1998; Pamenter et al., 2008). Furthermore, the increased ROS activity observed in mammalian brain during re-oxygenation (Granger and Kvietys, 2015; Coimbra-Costa et al., 2017) is absent from the turtle brain (Milton et al., 2007; Hogg et al., 2015). However, the crucian carp maintains neuronal activity and hence brain energy consumption to a much larger extent than turtles (Lutz and Nilsson, 1997). It cannot therefore be taken for granted that it is equally able to protect itself from apoptotic or even necrotic brain cell death, either during anoxia as a result of mitochondrial depolarization due to the lack of a terminal electron acceptor (i.e. oxygen) or during re-oxygenation as a result of increased ROS production.
Consequently, the overall objective of the present study was to examine whether anoxic and re-oxygenated crucian carp suffer from cell death in the brain accompanied by detrimental effects at the behavioural level, or whether the fish protects its brain against cell death during exposure to anoxia and re-oxygenation. To do so, we investigated three hypotheses. (1) Exposure to anoxia in the laboratory leads to increased cell death in the brain of crucian carp, either during anoxia or during recovery in normoxia (reoxygenation), or both, and cell proliferation is increased during re-oxygenation to counteract the increased cell death. (2) The hypothesized increase in cell death is apoptotic and involves caspase 3 activity. Hence, an increased expression of caspase 3 is expected in the brain of crucian carp exposed to anoxia in the laboratory and in the brain of wild crucian carp during seasonal exposure to anoxia and re-oxygenation. (3) The brain damage hypothesized to occur with anoxia and/or re-oxygenation is reflected in changes in behaviour, revealed as impaired memory or spatial learning ability.

\section{MATERIALS AND METHODS \\ Experiments}

The hypotheses were tested with three sets of experiments. Experiment 1: cell death (identified by the TUNEL assay) and cell proliferation [identified by immunohistochemical staining for proliferating cell nuclear antigen (PCNA) as well as measurement of PCNA mRNA expression] were quantified in the telencephalon of crucian carp. The telencephalon is the brain area proposed to contain the fish homologue of the mammalian hippocampus - a key area for learning and memory (Rodríguez et al., 2002). The measurements were done on crucian carp exposed to normoxia, anoxia or anoxia followed by re-oxygenation in the laboratory. Experiment 2: mRNA and protein expression of the protease caspase 3 was measured in whole brain from another set of crucian carp exposed to normoxia, anoxia or anoxia-re-oxygenation for the same durations as in experiment 1. mRNA and protein expression of caspase 3 was also measured in whole brain of crucian carp sampled from a small lake at five different time points over the year when oxygen levels in the lake cycled from normoxic to anoxic conditions (October, December, May, June, September). Experiment 3: the effect of anoxia-re-oxygenation on the spatial learning and memory ability of crucian carp was assessed by a series of maze trials.

\section{Animals}

Crucian carp, Carassius carassius (L. 1758), were obtained from the small lake Tjernsrudtjernet, near Oslo, Norway $\left(59^{\circ} 55^{\prime} 18.4^{\prime \prime} \mathrm{N}\right.$, $10^{\circ} 36^{\prime} 32.9^{\prime \prime} \mathrm{E}$ ), and the fish studied in the laboratory were kept in a 7501 holding tank (experiment 1 and 2) or multiple smaller glass aquaria (experiment 3 ) at the aquarium facilities at the Department of Biosciences, University of Oslo. The holding tanks were continuously supplied with aerated and de-chlorinated tap water $\left(\sim 21 \mathrm{~min}^{-1}\right)$, the temperature of which varied with season $\left(9-12^{\circ} \mathrm{C}\right)$. Light was kept on a $12 \mathrm{~h}$ dark: $12 \mathrm{~h}$ light cycle. The fish were fed daily with commercial carp food from at least 2 months and up to a year prior to experimentation to allow a build-up of sufficient glycogen stores, but food was withheld $24 \mathrm{~h}$ prior to tissue sampling experiments and for 3 days prior to the commencement of the maze experiments. All experiments were conducted on adult fish of both sexes.

In the laboratory, five separate sets of anoxia exposure were conducted for the present study: one for immunohistochemical measurements (hypothesis 1, experiment 1), one for protein and gene expression (hypotheses 1 and 2, experiments 1 and 2), and 
three for behavioural measurements (hypothesis 3, experiment 3). Additionally, crucian carp were collected in Tjernsrudtjernet on five different occasions (hypothesis 2, experiment 2): October 2010, December 2010, May 2011, June 2011 and September 2011. The anoxia-exposure experiments were carried out according to Norwegian animal research guidelines at an approved animal facility (Norwegian Animal Research Authority, approval no. 155/ 2008). The sample size in the different groups in the different experiments was kept to the minimum that allowed robust statistical comparison.

\section{General protocol for laboratory exposure to anoxia}

Two identical cylindrical dark tanks (251) were set up with a through-flow of water and air bubbling, one tank serving as the normoxic control tank and the other as the anoxia/re-oxygenation tank. Approximately 25 fish were acclimated to the tanks with a through-flow of aerated water for approximately $24 \mathrm{~h}$. Only half of the fish were sampled from the normoxic tank, but having the same fish density in each tank made the environment, except for the oxygen level, equal for the two groups. The fish were not fed during the experiment. To induce anoxia, nitrogen gas (AGA A/S, Oslo, Norway) was bubbled directly into the holding tank as well as into the incoming water through a long column connected to the tank with gastight tubing. Oxygen level and temperature were monitored daily in both tanks using a galvanic oxygen meter (Oxi3310, WTW, Weilheim, Germany). In all three experiments, the oxygen level was above $95 \%$ air saturation in the normoxic tank and below $0.1 \%$ air saturation in the anoxic tank, which was considered to be anoxia (Nilsson, 1989; Stensløkken et al., 2014). Following the anoxic period, nitrogen bubbling was replaced with air bubbling, resulting in re-oxygenation of the water and the fish. The normoxic control group and the anoxia group were sampled after 7 days (N7 and A7, respectively). The remaining fish in the anoxia group were sampled after 1 day of normoxia (A7R1) or 7 days of normoxia (A7R7), following the initial 7 days of anoxia. Upon termination of the experiment, the fish were stunned with a blow to the head, followed by cutting of the spinal cord and removal of the whole brain within $1 \mathrm{~min}$. The brain was frozen immediately in liquid nitrogen and stored at $-80^{\circ} \mathrm{C}$ until further use, unless otherwise indicated.

\section{Immunohistochemistry and sampling (hypothesis 1, experiment 1)}

These experiments were conducted in January 2009. Crucian carp ( $N=24$, body mass $43 \pm 11 \mathrm{~g}$ mean \pm s.d.) were exposed to normoxia, anoxia and re-oxygenation as described above ('General protocol for laboratory exposure to anoxia'). Fish were killed by decapitation, and the whole brain was dissected out and dropfixed in 4\% paraformaldehyde in $0.1 \mathrm{~mol} \mathrm{l}^{-1}$ phosphate-buffered saline (PBS). After $24 \mathrm{~h}$, the brains were transferred to $20 \%$ sucrose solution for another $24 \mathrm{~h}$, and finally placed in $30 \%$ sucrose solution for $24 \mathrm{~h}$. The brains were embedded in Tissue-Tek ${ }^{\circledR}$ O.C.T medium (Sakura Finetek, Inc., Torrance, CA, USA), and frozen in melting isopentane. The frozen brains were stored at $-80^{\circ} \mathrm{C}$, until sectioned at a thickness of $25 \mu \mathrm{m}$ using a cryostat (Microm HM 560, ThermoFisher Scientific Inc., Waltham, MA, USA) and mounted on SuperFrost ${ }^{\mathrm{TM}}$ Plus (ThermoFisher Scientific Inc.) slides. The slides were air dried at room temperature for $48 \mathrm{~h}$ and stored at $-80^{\circ} \mathrm{C}$.

\section{TUNEL assay}

Unless otherwise stated, all procedures were performed at room temperature. The slides were thawed, washed in PBS ( $\mathrm{pH} 7.4)$ for
$5 \times 5 \mathrm{~min}$, post-fixed in paraformaldehyde $(4 \%, 15 \mathrm{~min})$, and then washed (PBS, $3 \times 5 \mathrm{~min}$ ). Epitope retrieval was performed by incubation for $30 \mathrm{~min}$ in sodium citrate $\left(0.1 \mathrm{~mol} \mathrm{l}^{-1}, \mathrm{pH}\right.$ 6) containing $0.1 \%$ Triton X-100 (Sigma-Aldrich ${ }^{\circledR}$ Norway A/S, Oslo, Norway). After incubation, the sections were rinsed in PBS ( $3 \times 5 \mathrm{~min})$, and treated with $3 \% \mathrm{H}_{2} \mathrm{O}_{2}$ (Sigma-Aldrich) to inhibit peroxidase activity $(10 \mathrm{~min})$. After washing with PBS $(3 \times 5 \mathrm{~min})$, $50 \mu$ of terminal deoxynucleotidyl transferase $(\mathrm{TdT})$ reaction buffer $\left(25 \mathrm{mmol} \mathrm{l}^{-1}\right.$ Tris- $\mathrm{HCl}, 200 \mathrm{mmol} \mathrm{l}^{-1}$ sodium cacodylate, $0.25 \mathrm{mg} \mathrm{ml}^{-1}$ bovine serum albumin, $1 \mathrm{mmol}^{-1}$ cobalt chloride) was added to each section, and sections were incubated for $10 \mathrm{~min}$. Hereafter, the sections were incubated with $50 \mu \mathrm{l}$ each of TdT reaction mixture $\left[1600 \mathrm{U} \mathrm{ml}^{-1} \mathrm{TdT}\right.$ and $3.6 \mu \mathrm{mol} 1^{-1}$ biotin-16dUTP (Roche Diagnostics, Basel, Switzerland) in TdT reaction buffer] at $37^{\circ} \mathrm{C}$ in a humidity box for $1 \mathrm{~h}$. The reaction was stopped by washing with stop buffer $\left(300 \mathrm{mmol} \mathrm{l}^{-1} \mathrm{NaCl}, 30 \mathrm{mmol} \mathrm{l}^{-1}\right.$ sodium citrate) followed by $3 \times 5 \mathrm{~min}$ in PBS. The sections were then incubated with $50 \mu \mathrm{l}$ streptavidin-horseradish peroxidase (HRP) (ThermoFisher Scientific Inc.) for $20 \mathrm{~min}$ and washed $3 \times 5 \mathrm{~min}$ in PBS. Finally, peroxidase activity was visualized using 3,3'diaminobenzidine (DAB, $0.01 \mathrm{~mol} \mathrm{l}^{-1}$; PanReac Applichem, AppliChem $\mathrm{GmbH}$, Darmstadt, Germany) and $0.01 \% \mathrm{H}_{2} \mathrm{O}_{2}$ in PBS for $7 \mathrm{~min}$, washed $3 \times 5$ min with distilled water $\left(\mathrm{dH}_{2} \mathrm{O}\right)$ and cover-slipped using a permanent mounting medium. Positive controls were made by incubating sections with $50 \mu \mathrm{l}$ DNase I (20 $\mathrm{U} \mathrm{ml}^{-1}$, Invitrogen, ThermoFisher Scientific Inc.), prior to the labelling step. Negative controls were made by omitting TdT from the reaction mixture.

\section{PCNA staining}

The slides were thawed, washed in PBS $(5 \times 5 \mathrm{~min})$ and post-fixed in paraformaldehyde $(4 \%, 10 \mathrm{~min})$. Epitope retrieval was performed using a citric acid buffer $\left(10 \mathrm{mmol} \mathrm{l}^{-1}, \mathrm{pH} 6.0,85^{\circ} \mathrm{C}, 60 \mathrm{~min}\right)$. Slides were washed in PBS and unspecific binding blocked with $6 \%$ skimmed milk powder and $0.03 \%$ Triton X-100 (Sigma-Aldrich) in PBS. Sections were treated with primary antibody for $24 \mathrm{~h}$ at $4{ }^{\circ} \mathrm{C}$ [1:50, Rabbit Anti-PCNA (Dako, Agilent Technologies Inc., Santa Clara, CA, USA) in PBS with $0.6 \%$ skimmed milk powder and $0.03 \%$ Triton $\mathrm{X}-100$ ] and washed $3 \times 5$ min with PBS. This antibody has been shown to work for crucian carp in a previous study (Sollid et al., 2005). Endogenous peroxidase activity was blocked with 3\% $\mathrm{H}_{2} \mathrm{O}_{2}$ (Sigma-Aldrich, $15 \mathrm{~min}$ ) and the sections were then washed $3 \times 5$ min with PBS. Slides were incubated with secondary antibody for 30 min $\left(\right.$ EnVision ${ }^{\circledR}{ }^{\circledR}$ System Labelled Polymer-HRP, AntiRabbit, Dako) and washed $3 \times 5$ min with PBS. Finally, peroxidase activity was visualized using DAB $\left(0.01 \mathrm{~mol} \mathrm{l}^{-1}\right)$ and $0.01 \% \mathrm{H}_{2} \mathrm{O}_{2}$ in PBS for $15 \mathrm{~min}$, washed $2 \times 5$ min with $\mathrm{dH}_{2} \mathrm{O}$ and cover-slipped using permanent mounting medium.

\section{Image preparation and analysis}

For quantification of TUNEL- and PCNA-positive nuclei, an Olympus BX50WI microscope with a ColorView camera (1288×966 pixel resolution) and Olympus Cell B software were used. Pictures were taken at $20 \times$ magnification and merged using Olympus Cell B and Photoshop CS3 software. Every fourth section (one $25 \mu \mathrm{m}$ section per $100 \mu \mathrm{m}$ ) throughout the telencephalon was analysed, and pre-optic areas were excluded when they appeared in the same sections. Rather than analysing sections throughout the whole brain, the telencephalon was chosen because of its proposed homology to the mammalian hippocampus. Only nuclei with intact nuclear membranes as well as positive TUNEL staining were counted. The analysed volume was found from the area of each 
section, determined using Photoshop CS3 software, and the section thickness $(25 \mu \mathrm{m})$. The number of TUNEL- and PCNA-positive cells per analysed tissue volume was calculated by dividing the total number of stained nuclei for all sections counted in the telencephalon from each fish by the total analysed volume for each fish.

\section{Gene and protein expression measurements (hypotheses 1 and 2, experiments 1 and 2)}

The experimental animals ( $N=40$, body mass $33 \pm 13$ g mean \pm s.d.) for this experiment were caught in Tjernsrudtjernet in August 2012 and the exposure was conducted in September 2013 as described under 'General protocol for laboratory exposure to anoxia', above. Brain tissue was also obtained from fish of both sexes that had been sampled after capture at Tjernsrudtjernet $(N=39$, body mass $49 \pm 11 \mathrm{~g})$ on 31 October $2010(n=8), 9$ December $2010(n=8)$, 2 May $2011(n=8), 16$ June $2011(n=7)$ and 14 September 2011 $(n=8)$. Both temperature and oxygen concentration were measured in the pond at the time of sampling (using a WTW Oxi3310 oxygen meter) and captured fish were immediately transported to the University of Oslo in plastic bags containing pond water. Fish were maintained in the bags until sampled (maximum $2 \mathrm{~h}$ after capture), during which time water temperature and oxygen level were regulated to be consistent with the natural conditions. Low temperature was maintained by placing the bags on ice, and hypoxic or anoxic conditions were maintained by bubbling the water at an appropriate rate with $\mathrm{N}_{2}$. Whole brain tissue was sampled as described under 'General protocol for laboratory exposure to anoxia', above.

\section{Protein extraction, total RNA extraction and cDNA synthesis}

Total RNA and total protein from the brain tissue were extracted with the PARISTM Kit (Life Technologies, Carlsbad, CA, USA) according to the manufacturer's protocol, except that 5\% isoamyl alcohol (Merck Millipore, Billerica, MA, USA) was added to the cell disruption buffer prior to homogenization, to reduce foaming. All samples were randomized upon extraction. An external RNA control (20 pg mw2060 per mg of tissue) was added during RNA isolation (Ellefsen et al., 2008). Because of the viscous condition of the solution, all samples were drawn through a 27 gauge syringe (Becton Dickinson, NJ, USA). Total RNA was DNase treated with TURBO DNA-free ${ }^{\mathrm{TM}}$ Kit (Life Technologies) according to the manufacturer's protocol, and RNA quantity and quality were assessed using a NanoDrop 2000 UV-Vis Spectrophotometer (ThermoFisher Scientific Inc.) and 2100 Bioanalyzer (Agilent Technologies, Palo Alto, CA, USA), respectively. RNA quality was determined from RNA integrity number (RIN) calculated by the 2100 Bioanalyzer (range 1-10). The RIN for the tissue samples had a mean ( \pm s.e.m.) of $7.17 \pm 0.13$, confirming good RNA quality. The cDNA was made from $260.7 \mathrm{ng}$ RNA (based on the lowest concentration) with Oligo(dT) $)_{12-18}$ (Life Technologies) and SuperScript ${ }^{\mathrm{TM}}$ III Reverse Transcriptase (Life Technologies).

\section{Partial cloning and sequencing of caspase 3}

Partial cloning was carried out to obtain the crucian carp mRNA sequence for caspase 3 genes. Two paralogues have already been identified in zebrafish: caspase 3a (casp3a) and 3b (casp3b) (NCBI database reference sequence numbers NM_131877.3 and NM_001048066.1, respectively). The proteins encoded by these sequences are roughly the same size, with some very similar and some less similar areas (see Fig. S1). Partial cloning primers were designed using Primer3 (Rozen and Skaletsky, 2000) based on the casp3a and casp3b sequences from zebrafish as well as other sequences from vertebrates available in the NCBI database. The primers (see Table 1) were synthesized by Life Technologies. PCR (Eppendorf Mastercycler gradient, Eppendorf AG, Hamburg, Germany) was performed on cDNA from crucian carp brains using Platinum ${ }^{\circledR}$ Taq DNA Polymerase and dNTP mix (Life Technologies) according to the manufacturer's protocol. The following PCR program was used: (1) $94^{\circ} \mathrm{C}$ for $10 \mathrm{~min}$, (2) $94^{\circ} \mathrm{C}$ for $30 \mathrm{~s}$, (3) $48^{\circ} \mathrm{C}$ for $1 \mathrm{~min}$ (if several fragments or a smear appeared in the agarose gel, $55^{\circ} \mathrm{C}$ was used instead), (4) $72^{\circ} \mathrm{C}$ for $1 \mathrm{~min}$ (predicted fragment size less than $1 \mathrm{~kb}$ ); steps $2-4$ were repeated 39 times, followed by $(5) 72^{\circ} \mathrm{C}$ for $10 \mathrm{~min}$, and (6) hold $4^{\circ} \mathrm{C}$. PCR products were run on a $1 \%$ agarose gel with ethidium bromide (Sigma-Aldrich), 10 $\times$ BlueJuice $^{\mathrm{TM}}$ Gel Loading Buffer (Life Technologies) and $1 \mathrm{~kb}+$ DNA ladder (Life Technologies). Fragments of the expected size were ligated into vectors using the pGEM $^{\circledR}$-T Easy Vector System I (Promega, Fitchburg, WI, USA) and transformed in $\mathrm{CaCl}_{2}$-competent $E$. coli cells (produced from stock at the University of Oslo) by heat-shock treatment. The bacteria were grown on lysogeny broth (LB) plates containing ampicillin and a mix of isopropyl $\beta$-D-1-thiogalactopyranoside (IPTG) and 5-bromo-4-chloro-3-indolyl- $\beta$-D-galactopyranoside (X-Gal; Promega). Colony PCR with M13F2 and M13R (Life Technologies) primers and subsequent gel electrophoresis were performed to obtain sequences of the genes of interest. The following PCR program was used: (1) $94^{\circ} \mathrm{C} 10 \mathrm{~min}$, (2) $94^{\circ} \mathrm{C} 30 \mathrm{~s}$, (3) $55^{\circ} \mathrm{C} 1 \mathrm{~min}$, (4) $72^{\circ} \mathrm{C} 1 \mathrm{~min}$; steps $2-4$ were repeated 35 times, followed by $(5) 72^{\circ} \mathrm{C} 10 \mathrm{~min}$, and (6) hold $4^{\circ} \mathrm{C}$. The fragments were purified with Illustra ExoProStar 1-Step (GE Healthcare Life Sciences, Little Chalfont, UK), and sequenced with the M13F primer at the ABI-lab (the Norwegian Sequencing Centre, Department of Biosciences, University of Oslo).

Table 1. Primers used for partial cloning of crucian carp casp3a and casp3b and quantitative real-time PCR of mw2060 (external standard) and crucian carp casp3a, casp3b and PCNA

\begin{tabular}{|c|c|c|}
\hline Gene & Direction & Primer sequence $\left(5^{\prime} \rightarrow 3^{\prime}\right)$ \\
\hline \multicolumn{3}{|l|}{ Partial cloning } \\
\hline \multirow[t]{9}{*}{ casp3a } & $\mathrm{F} 1$ & AGCCTCAACTACCCCAACAT \\
\hline & $\mathrm{F} 2$ & GAACACAGGCATGAACCCAC \\
\hline & F3 & GTTGCCCATGACGATCACAG \\
\hline & $\mathrm{F} 4$ & ARCCTCAACTACCCCAACMT \\
\hline & F5 & 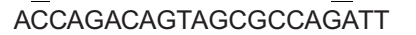 \\
\hline & F6 & AGTCGCTGTGCTTCATTTGT \\
\hline & $\mathrm{R} 1$ & TCAAGCGCTGAAGTACATCTC \\
\hline & R2 & TGTTTCTTAGAGTCGAAGTCAG \\
\hline & R5 & GAGGAAGTCTGCCTCCACA \\
\hline \multirow[t]{2}{*}{ casp3b } & $\mathrm{F} 2$ & CAACGGGACAGACAAGGATG \\
\hline & $\mathrm{R} 2$ & CATCAAACCCTGGAAGATTGCA \\
\hline \multicolumn{3}{|l|}{ qPCR } \\
\hline \multirow[t]{2}{*}{ mw2060 } & $\mathrm{F}$ & CTGACCATCCGAGCGATAAT \\
\hline & $\mathrm{R}$ & AGCAAGCTGTTCGGGTAAAA \\
\hline \multirow[t]{2}{*}{ casp3a } & $\mathrm{F}$ & GTGTGTGTGATGCTCAGTCA \\
\hline & $\mathrm{R}$ & CCACACCAGGATCCAGTTCT \\
\hline \multirow[t]{2}{*}{ casp3b } & $\mathrm{F}$ & AGCAACTGTTTACACTCTTCAGA \\
\hline & $\mathrm{R}$ & AACCAGGAACCATTGCCAAC \\
\hline \multirow[t]{2}{*}{ PCNA } & $\mathrm{F}$ & CTTTGGCACTTGTCTTTGAAAC \\
\hline & $\mathrm{R}$ & TTCACCACACAGCTGTATTCCT \\
\hline
\end{tabular}

$F$, forward primer; $R$, reverse primer. Several primers for each gene were designed for the partial cloning, but this table only shows the primers that obtained the correct sequence. The F4 primer for casp3a has a degenerative code where $\mathrm{R}$ is $\mathrm{G}$ or $\mathrm{A}$, and $\mathrm{M}$ is $\mathrm{A}$ or $\mathrm{C}$. The primer pairs chosen for qPCR were based on the lowest crossing point (CP) value, best efficiency, and the primer that gave only one melting curve with SYBR Green I detection. The primer sequence for PCNA was obtained from Sandvik et al. (2012). 


\section{Quantitative real-time PCR of casp3a, casp3b and PCNA}

Primers for quantitative real-time PCR (qPCR) were designed based on the sequences obtained from partial cloning and sequencing of the three products found in crucian carp, i.e. casp3ai, casp3aii and casp3b (NCBI GenBank accession numbers MF288604, MF288605 and MF288603, respectively) using the Primer3 online utility (Koressaar and Remm, 2007; Untergasser et al., 2012). The primer pairs were designed to bind at exon-intron boundaries and all primer pairs gave only one melting curve with the LightCycler $^{\circledR} 480$ SYBR Green I Master (Roche) detection. The qPCR products were subsequently cloned and sequenced as described above to confirm that the correct sequences were amplified by the qPCR primers. The primer pair used for casp3a picked up both paralogues obtained in the partial cloning experiment (casp3ai and casp3aii). qPCR primers for the proliferation marker PCNA were obtained from Sandvik et al. (2012). Primer pairs used in the qPCR assay are listed in Table 1. qPCR was performed using the LightCycler ${ }^{\circledR} 480$ Real-Time PCR System with LightCycler ${ }^{\circledR} 480$ SYBR Green I Master according to the manufacturer's protocol. All samples were randomized during the qPCR experiment, and run in duplicate. The following qPCR program was used: (1) pre-incubation $\left(95^{\circ} \mathrm{C} 10 \mathrm{~min}\right)$, (2) three-step amplification $\left(95^{\circ} \mathrm{C} 10 \mathrm{~s}, 60^{\circ} \mathrm{C} 10 \mathrm{~s}, 72^{\circ} \mathrm{C} 10 \mathrm{~s}\right)$, (3) melting $\left(95^{\circ} \mathrm{C}\right.$ $\left.5 \mathrm{~s}, 65^{\circ} \mathrm{C} 60 \mathrm{~s}, 97^{\circ} \mathrm{C} 1 \mathrm{~s}\right)$ and $(4)$ cooling $\left(1^{\circ} \mathrm{C} 10 \mathrm{~s}\right)$. Step 2 was repeated 42 times. Primer efficiency was calculated with LinReg software (version 1.0.0.0) (Ruijter et al., 2013), and an average efficiency for each primer pair in each duplicate was utilized in the final calculations of gene expression levels. All data were normalized by using the relative expression ratio between mw2060 and the gene of interest using the second derivative maximum method to calculate the expression level for each gene (Ellefsen et al., 2008; see Eqn 1) where $E$ is the priming efficiency and $\mathrm{CP}$ is the crossing point:

$$
\text { mRNA expression level }=\frac{E_{\text {standard gene }}^{\mathrm{CP}_{\text {standard gene }}}}{E_{\text {target gene }}^{\mathrm{CP}_{\text {target gene }}}} .
$$

\section{Western blotting of caspase $\mathbf{3 a}$}

Protein levels of casp3a were analysed in whole brain from both laboratory-exposed and wild-caught crucian carp by Western blotting. Prior to the experiment, all protein lysates were centrifuged at $12,000 \mathrm{~g}$ for $10 \mathrm{~min}$ at $4^{\circ} \mathrm{C}$, in order to obtain a rough cytoplasmic lysate. Based on a high conservation in amino acid alignment (sequences obtained by cloning were translated to amino acid sequences and aligned with zebrafish casp3a; see Fig. S1), a primary antibody against zebrafish casp3a p17 [Anti-Caspase-3a (p17) NT, Z-Fish ${ }^{\mathrm{TM}}$, cat. no. 55371, lot no. NA2301, AnaSpec Inc., Freemont, CA, USA), which is situated on the small subunit cleaved from casp3a during activation, was utilized. This antibody is thus expected to bind both to the inactive pro-caspase (showing a band at $32 \mathrm{kDa}$ ) and to the cleaved, active form of casp3a (showing a band at $17 \mathrm{kDa}$ ). The primary antibody was tested on a positive control, consisting of apoptotic gill tissue from crucian carp exposed to high temperature $\left(25-30^{\circ} \mathrm{C}\right.$; Sollid and Nilsson, 2006). The positive control showed the expected band at $17 \mathrm{kDa}$ (cleaved, active caspase 3) and a weaker band at $58 \mathrm{kDa}$, which was more pronounced in the brain tissue, where both the 17 and the $32 \mathrm{kDa}$ (non-cleaved, inactive caspase 3 ) bands were visible (see Fig. S2).

Protein samples were prepared with $2 \times$ Laemmli sample buffer, and loaded on a NuPAGE ${ }^{\circledR}$ Novex $^{\circledR} 4-12 \%$ Bis-Tris Protein Gel
(Life Technologies). The gels were run with XT MES Running Buffer (Bio-Rad Laboratories, Hercules, CA, USA) at $200 \mathrm{~V}$ for 35 min. NuPage ${ }^{\mathbb{R}}$ Antioxidant (Life Technologies) was added to the running buffer in the inner chamber to keep the proteins in a reduced state. Proteins separated on the gels were transferred to a $0.45 \mu \mathrm{m}$ polyvinylidene difluoride (PVDF) membrane (Life Technologies), and blotted with $1 \times$ transfer buffer at $150 \mathrm{~V}$. The membranes were blocked in a 5\% skimmed milk powder solution dissolved in Trisbuffered saline and Tween 20 (TBST). Blots were incubated with a 1:1000 dilution of primary antibody and a 1:10,000 dilution of secondary antibody [goat anti-rabbit IgG HRP conjugated (AnaSpec)]. Amersham ECL Prime Western Blotting Detection Reagent (GE Healthcare Life Sciences) was added prior to imaging with a Kodak 4000r Pro image station (Kodak, Rochester, NY, USA). The blots were then stained with Coomassie Brilliant Blue (PhastGELTM BlueR, GE Healthcare Life Sciences) for quantification of total loaded protein. Calculations were performed using ImageQuant software (version TL 8.1, GE Healthcare Life Sciences). Animals from one of the experimental groups (A7, A7R1 or A7R7 and October 2010, December 2010, May 2011 or September 2011) and animals from the control group (N7 or June 2011), were analysed on the same blot in order to compare quantification between different blots. The intensity $(I)$ of each band of interest was normalized to total loaded protein within the same lane (see Eqn 2), and then normalized to an average of all control ratios for the target protein within the same blot. Only the $17 \mathrm{kDa}$ bands, representing the cleaved and active form of casp3a, were quantified and used for further analysis:

Normalized protein expression $=\frac{\left(I_{\text {target protein }} / I_{\text {total protein }}\right)}{\text { Average ratio for target protein }}$.

\section{Memory and spatial learning experiments (hypothesis 3, experiment 3)}

The experimental animals ( $N=53$, body mass $33 \pm 12$ g mean \pm s.d.) utilized for these experiments were caught in Tjernsrudtjernet in the autumn of 2010 and summer of 2011. Fish were maintained as described above (see Materials and methods, 'Animals', above) at water temperatures that followed the season. Experiments were performed from February to September of 2011, at which time the water temperature ranged between 11 and $12^{\circ} \mathrm{C}$.

The effects of anoxia and subsequent re-oxygenation on the ability of the crucian carp to recall a previously learned task, as well as on the spatial learning ability of the fish, were assessed using a maze system based on that of Girvan and Braithwaite (2000) and Sloman (2010). Three mazes were constructed by horizontally dividing a rectangular PVC box into four equally sized areas (see Fig. S3A). Each partition contained two openings, one through which the fish could progress to the next partition and one that led to a dead end. Two separate experiments (schematically represented in Fig. S3B,C and detailed below) were conducted to assess whether crucian carp show impaired memory and/or impaired learning after anoxia-re-oxygenation. Preliminary experiments revealed that fish that first experienced the maze individually were hesitant to explore the set-up and unlikely to successfully navigate the maze, even if provided with numerous opportunities to explore. Thus, both the memory and learning experiments included initial group training sessions, where groups of three (learning experiment) or six (memory experiment) fish were placed together to explore the maze (with the presence of the food reward) for $1 \mathrm{~h}$ a day for 5 consecutive 
days prior to conducting individual trials. During each individual trial, a food reward was placed in the end of the last compartment of the maze, and the fish was placed in the first compartment. After a $1 \mathrm{~h}$ habituation period in the start section (which was closed off from the rest of the maze by a removable screen), the partition was opened and the fish was allowed to explore the maze. Two parameters were measured during each individual trial: (1) the time it took the fish to pass through the maze and reach the food item; and (2) the number of times the fish made a mistake by going through an opening that led to a dead end or turning around and going back through an opening that it had already passed through. Fish were returned to their respective tanks between trials and food was withheld during the period of time that fish partook in the group training and individual trials.

\section{Protocol for the memory experiment}

For the experiment designed to investigate how exposure to anoxia and re-oxygenation affected memory of a previously learned behaviour, fish were deprived of food for 3 days, subjected to group training sessions for 5 consecutive days, allowed a 2 day break from the maze and then subjected to five individual trials that occurred every other day over 10 days (see Fig. S3B). Fish were then exposed to anoxia or control normoxia, as detailed in 'General protocol for laboratory exposure to anoxia', above, and returned to their respective tanks. Twenty-four hours after the conclusion of anoxia or control normoxia exposure, each fish was tested once in the maze, and the post-exposure time to find food and number of errors were recorded. Fish that failed to find the food in three out of the five individual trials (two out of nine fish in each group) were excluded from analysis. As we found most TUNEL-positive cells following 1 day of re-oxygenation in the previous experiment, fish in this experiment were exposed to 5 days of anoxia followed by 1 day of re-oxygenation (anoxia group, final sample size of $n=7$ ) or 5 days of control normoxia followed by an additional day of normoxia (normoxia group, final sample size of $n=7$ ).

\section{Protocol for the learning experiment}

For the experiment designed to investigate how exposure to anoxia and re-oxygenation affected learning ability, 35 fish were deprived of food for $24 \mathrm{~h}$, exposed to 5 days of anoxia or 5 days of control normoxia, as detailed in 'General protocol for laboratory exposure to anoxia', above, subjected to group training sessions for 5 consecutive days (control normoxic and anoxia-exposed fish were not mixed in group training), allowed a 2 day break from the maze and then subjected to five individual trials that occurred every other day over 10 days (see Fig. S3C). Anoxia-exposed fish in this experiment were thus exposed to a total of 18 days of reoxygenation and the learning trials occurred from day 8 to 18 of re-oxygenation. As in the memory experiment, fish that failed to successfully navigate the maze in three out of the five individual trials ( 10 out of 18 normoxic fish and 8 out of 17 anoxic fish) were excluded from analysis.

\section{Assessment of feeding activity after exposure to anoxia}

As the memory and learning experiments relied on food as the incentive for successfully navigating the maze, observations were conducted to assess feeding activity of the anoxia- and normoxiaexposed fish. Crucian carp acclimated to $11-12^{\circ} \mathrm{C}(N=22$, body mass $32 \pm 7 \mathrm{~g}$ mean \pm s.d. $)$ were exposed to anoxia $(n=10)$ or control normoxia $(n=12)$ for 5 days as detailed in 'General protocol for laboratory exposure to anoxia', above. Twenty-four hours postexposure, groups of two normoxia- or two anoxia-exposed fish were randomly placed into one of the separated partitions of the three mazes. After a $1 \mathrm{~h}$ habituation period, four food pellets were added to each of the four partitions and the feeding activity of the fish was monitored for $1 \mathrm{~h}$. The feeding trials were repeated every second day over 10 days for a total of five trials and fish were not fed outside of the trials during this period. Feeding activity was quantified as the percentage of fish feeding (number of groups of fish feeding divided by the total number of groups) and the percentage of pellets consumed over the $1 \mathrm{~h}$ period (number of pellets consumed divided by the total number of pellets).

\section{Statistics}

All data were analysed and figures prepared using Prism v7.02 (GraphPad Software, Inc., La Jolla, CA, USA). The count data for TUNEL- and PCNA-stained cells, as well as the number of navigational errors counted in both of the behavioural experiments, were square-root transformed before statistical analysis to obtain normality and variance homogeneity. In cases of non-normality or variance non-homogeneity, data were $\log _{10}$ transformed to fulfil the assumptions of the ANOVA (PCNA and casp3a mRNA expression from laboratory-exposed fish, casp3a mRNA and protein expression from wild-caught crucian carp). The TUNEL- and PCNA-positive cell counts as well as mRNA and protein expression from both laboratory-exposed and wild-caught fish were analysed using a oneway ANOVA. All one-way ANOVA with significant effects were followed by Tukey's multiple comparison tests. A two-way ANOVA without repeated measures (because not all fish completed all five trials) was used to analyse the effect of trial number and treatment group on the time taken to find food and the number of navigational errors, before anoxia exposure in the memory experiment and after anoxia exposure in the learning experiment. A two-way ANOVA with repeated measures was used to compare treatment groups preand post-exposure. The two-way ANOVA were followed by Sidak's multiple comparisons. $P<0.05$ was considered significant.

\section{RESULTS}

\section{Cell death and cell proliferation}

There was a pronounced effect of treatment on the number of TUNEL-positive cells in the telencephalon of crucian carp (Fig. 1A; one-way ANOVA, $F_{3,20}=27.35, P<0.0001$; see also Fig. S4). The number of TUNEL-positive cells was higher in anoxia-exposed fish that were re-oxygenated for $24 \mathrm{~h}$ (A7R1) than in control normoxic fish (N7; Tukey's multiple comparison, $P<0.0001$ ), anoxiaexposed, but not re-oxygenated fish $(\mathrm{A} 7 ; P<0.001)$ and fish exposed to anoxia and 7 days of re-oxygenation (A7R7; $P<0.0001$ ). However, the increase in the number of TUNEL-positive cells was transient, as it was not significantly different from the normoxic control (N7) after 7 days of re-oxygenation (A7R7; $P=0.1278$ ). The number of cells that stained positive for PCNA did not differ significantly between the treatment groups (Fig. 1B; one-way ANOVA, $\left.F_{3,20}=0.4552, P=0.7166\right)$. mRNA expression of PCNA, however, was significantly affected by treatment (Fig. 1C; one-way ANOVA, $\left.F_{3,35}=4.753, P=0.007\right)$, and there was a higher PCNA mRNA expression in A7R7 than in N7 (Tukey's multiple comparison, $P=0.0062)$ and A7R1 $(P=0.0375)$ fish.

\section{Caspase 3 expression in laboratory-exposed and wild- caught crucian carp}

Western blotting revealed a weak whole-brain expression of the cleaved (active) form of casp3a (17 kDa) (Fig. S5A), which was only marginally affected by treatment (Fig. 2A; one-way ANOVA, $\left.F_{3,32}=3.251, P=0.0345\right)$, being lower in A7R7 than in A7R1 fish 

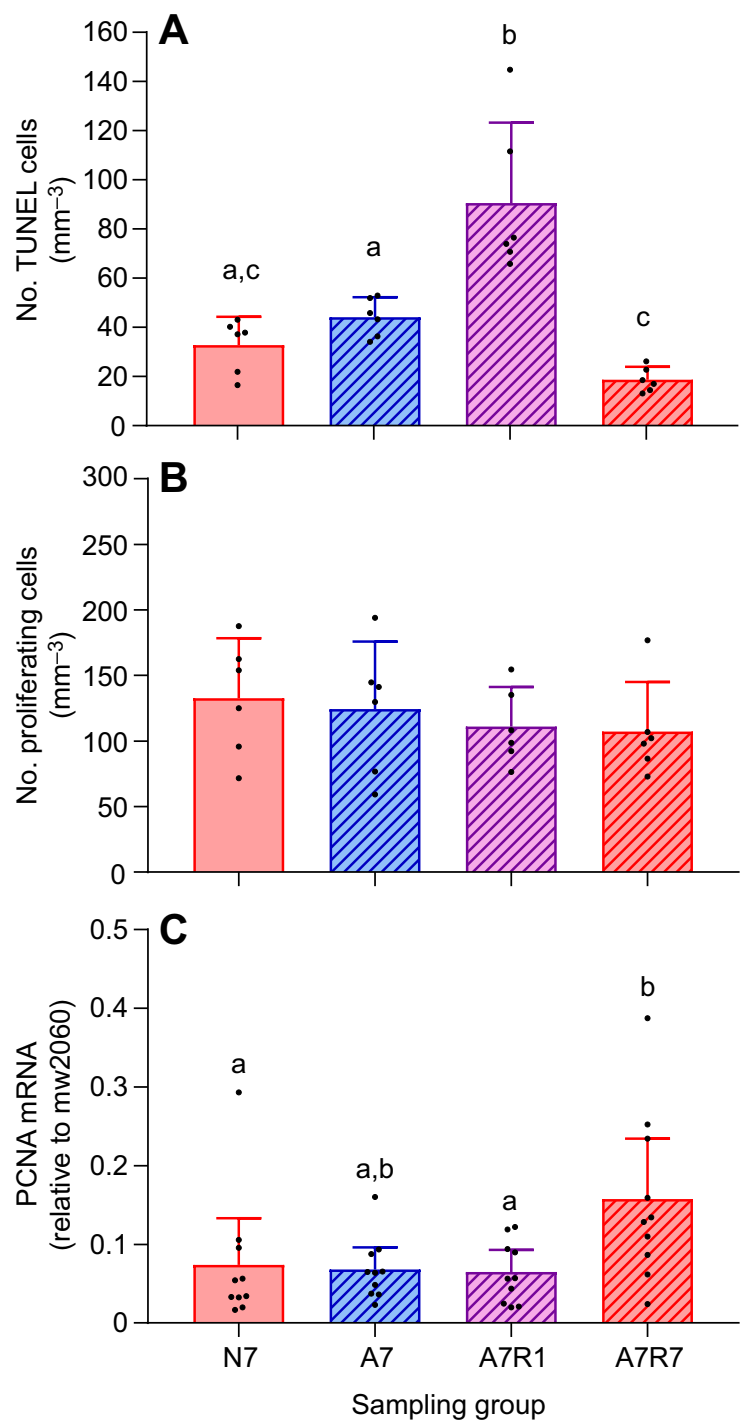

Fig. 1. Cell death and proliferation in crucian carp brain. (A) Number of TUNEL-positive cells per investigated volume in the telencephalon of crucian carp ( $n=6$ in each group), (B) number of proliferating cells as visualized by immunohistochemical staining for PCNA in the telencephalon ( $n=6$ in each group) and (C) crucian carp whole-brain mRNA expression of PCNA relative to external standard (mw2060) ( $n=10$ in each group), after exposure to normoxia for 7 days (N7), anoxia for 7 days (A7) or anoxia for 7 days followed by reoxygenation for 1 or 7 days (A7R1 and A7R7, respectively). Data are means $\pm 95 \%$ confidence interval $(\mathrm{Cl})$ with individual values indicated by dots. Different letters indicate significant differences (Tukey's multiple comparison).

(Tukey's multiple comparison, $P=0.044$ ). The mRNA expression of casp3a, however, was significantly affected by treatment (Fig. 2B; one-way ANOVA, $F_{3,36}=4.037, P=0.0142$ ). Contrary to protein expression, the average mRNA expression was lowest for A7R1, and highest in N7 and A7R7 fish, though the differences were only significant between A7R7 and A7R1 $(P=0.0076)$. The overall mRNA expression of casp3b was 20-25 times lower than the casp3a mRNA expression, but was similarly affected by treatment (Fig. 2C; one-way ANOVA, $F_{3,36}=6.003, P=0.002$ ). This was due to A7R7 fish having a higher expression than N7 (Tukey's multiple comparison, $P=0.004), \mathrm{A} 7(P=0.0073)$ and A7R1 $(P=0.0295)$ fish.

Oxygen levels and temperature in Tjernsrudtjernet on the dates crucian carp were captured showed a seasonal pattern, being highest in June, decreasing slightly in September, and reaching the lowest
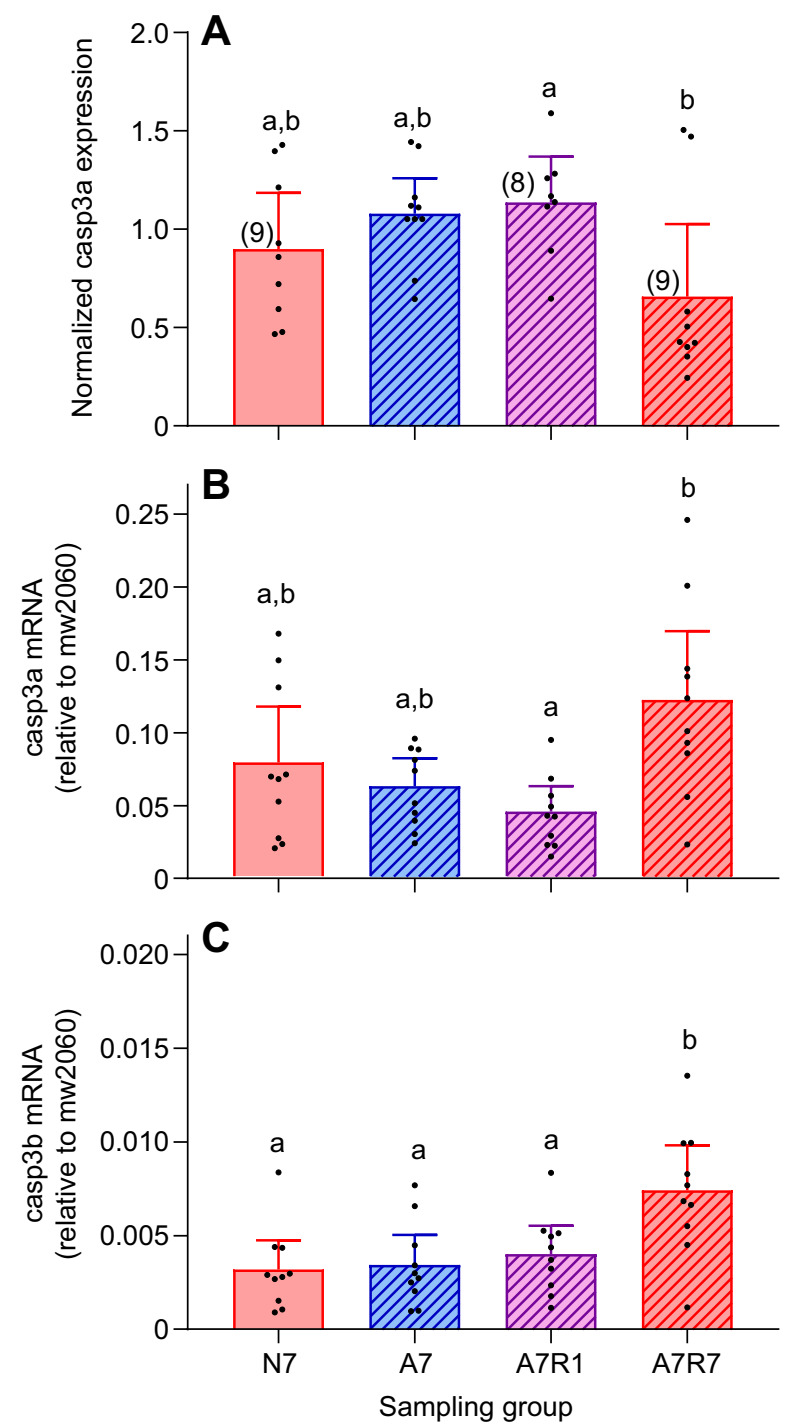

Fig. 2. Caspase 3 expression in crucian carp brain. (A) Protein expression [normalized to loaded protein as well as normoxic (N7) intensity within each blot] of the cleaved, active casp3a $(17 \mathrm{kDa})$, and $(\mathrm{B}, \mathrm{C})$ mRNA expression (relative to external standard, mw2060) of casp3a (B) and casp3b (C) in crucian carp after exposure to normoxia for 7 days (N7), anoxia for 7 days (A7) or anoxia for 7 days followed by re-oxygenation for 1 or 7 days (A7R1 and A7R7, respectively). Sample size was 10 in each group unless otherwise indicated (in parentheses). Data are means $\pm 95 \% \mathrm{Cl}$ with individual values indicated by dots. Different letters indicate significant differences (one-way ANOVA followed by Tukey's multiple comparison).

levels in October and December, and increasing again in May (Fig. 3A). In the summer, temperature was $13-18^{\circ} \mathrm{C}$ and daytime oxygen was $120-170 \%$ air saturation, suggesting a very high photosynthetic activity. During the winter, temperature was below $4^{\circ} \mathrm{C}$ and oxygen was close to $0 \%$ air saturation in December. There was a significant effect of sampling month on casp3a mRNA expression (Fig. 3B; one-way ANOVA, $F_{4,34}=23.76, P<0.0001$ ). Expression was much lower in October and December than in May, June and September (Tukey's multiple comparison, $P<0.005$ for all). As observed for the laboratory-exposed fish, expression of the cleaved casp3a (17 kDa) was weak (Fig. S5B). Nonetheless, the protein expression of cleaved casp3a was marginally affected by sampling month (Fig. 3C; one-way ANOVA, $F_{4,33}=2.701$, $P=0.0474)$ as a result of slightly higher expression in May 

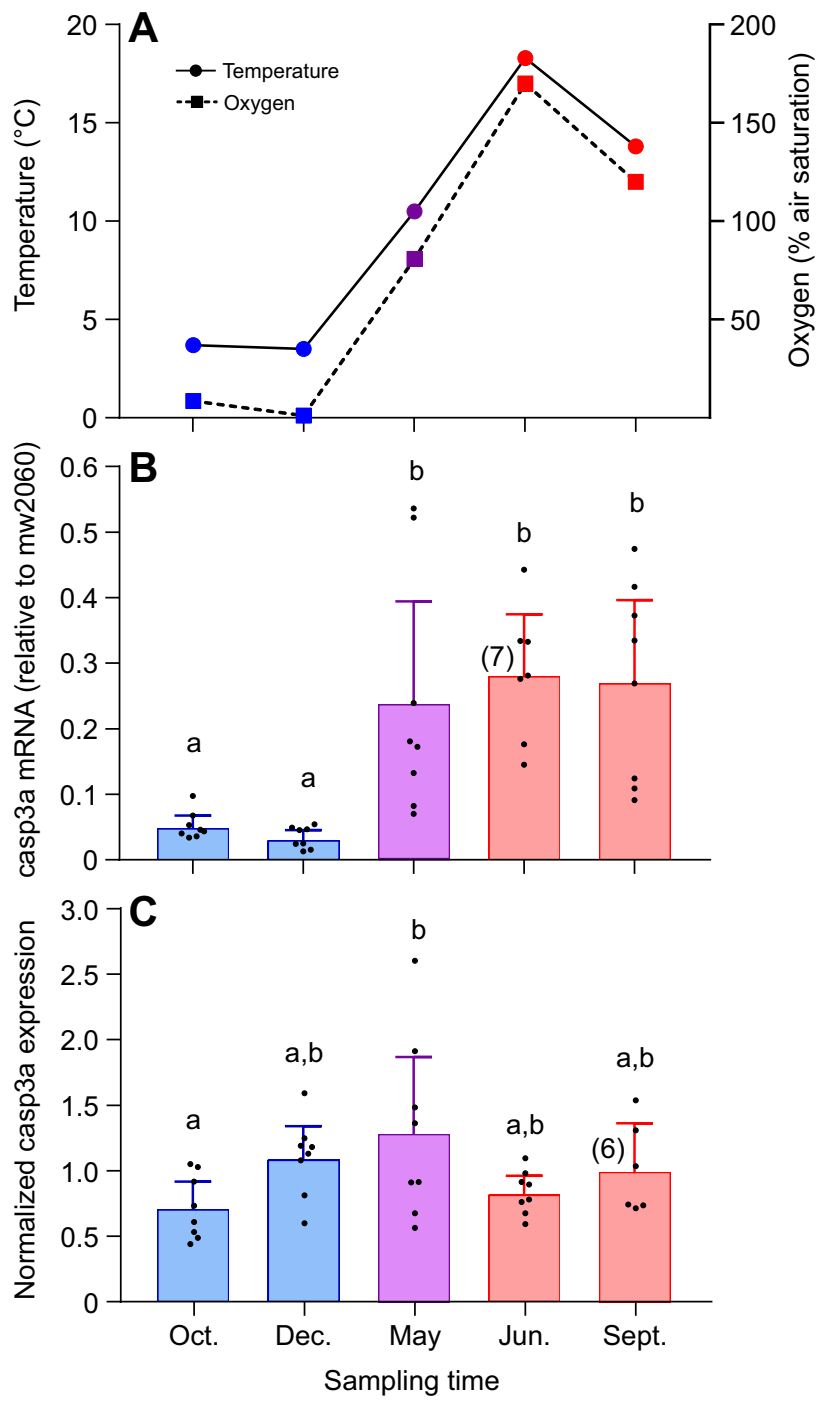

Fig. 3. Seasonal changes in temperature, oxygen level and caspase 3 expression in wild-caught crucian carp. (A) Temperature and oxygen level in Tjernsrudtjernet at the time of sampling. (B) mRNA expression of casp3a relative to external standard (mw2060) and (C) protein expression of cleaved, active casp3a normalized to total protein loading and June levels within each blot in whole brain from crucian carp exposed to natural temperature and oxygen levels. Sample size was 8 in each group unless otherwise indicated (in parentheses). Data in $\mathrm{B}$ and $\mathrm{C}$ are means $\pm 95 \% \mathrm{Cl}$ with individual values indicated by dots. Different letters indicate significant differences (Tukey's multiple comparison tests).

compared with October (Tukey's multiple comparisons test, $P=0.0479$ ).

\section{Effect of anoxia on memory and learning}

In the memory experiment, the normoxia and anoxia treatment groups were equally able to learn to find food in the maze, pre-exposure (Fig. 4A,B). There was no interaction between individual trial number and treatment group (two-way ANOVA; $\left.F_{4,54}=0.727, P=0.5774\right)$, no overall treatment effect $\left(F_{1,54}=1.098\right.$, $P=0.2993$ ), and the time to find food (Fig. 4A) decreased progressively with individual trial number $\left(F_{4,54}=3.531\right.$, $P=0.0124)$. Specifically, the time to successfully navigate the maze was shorter in individual trials 3, 4 and 5 compared with individual trial 1 (main effect of individual trial, Tukey's multiple comparisons test; $P<0.05$ for all). The number of navigational errors
(Fig. 4B) also appeared to decrease with individual trial number for both treatment groups before exposure, but there was no statistically significant effect of trial number (two-way ANOVA, $F_{4,60}=2.185$, $P=0.0815)$, no interaction $\left(F_{4,60}=2.077, P=0.0951\right)$ and no effect of treatment group $\left(F_{1,60}=0.5584, P=0.4578\right)$.

When comparing the pre- and post-exposure time taken to successfully navigate the maze and find food between the normoxia and anoxia group (Fig. 4C), there was no statistically significant effect of treatment group (two-way ANOVA with repeated measures, $\left.F_{1,12}=3.336, P=0.0928\right)$, time $\left(F_{1,12}=0.8525, P=0.374\right)$ or their interaction $\left(F_{1,12}=2.091, P=0.1738\right)$. Specifically, there was no difference between the two treatment groups pre-exposure (Sidak's multiple comparison, $P=0.9548$ ), or between pre- and postexposure for the control normoxic fish $(P=0.9206)$. However, the time to find food tended to be longer for the anoxia group postexposure compared with pre-exposure $(P=0.2251)$ and compared with the normoxic group post-exposure $(P=0.0581)$, though this effect was probably driven by two individuals performing particularly poorly. However, when comparing the number of navigational errors before and after exposure (Fig. 4D), there was a significant interaction between time and treatment (two-way ANOVA with repeated measures, $F_{1,12}=8.441, P=0.0132$ ), and an overall significant effect of treatment group $\left(F_{1,12}=12.03\right.$, $P=0.0046)$ and time $\left(F_{1,12}=7.384, P=0.0187\right)$. The number of errors was significantly higher in the anoxia group post-exposure compared with pre-exposure (Sidak's multiple comparison, $P=0.0037)$ and compared with the control normoxic fish $(P=0.0003)$. There was no difference in the number of errors between the pre- and post-exposure trial within the normoxia group ( $P=0.9893$ ), or when comparing the anoxia and normoxia group pre-exposure $(P=0.9975)$.

The ability to learn to find food in the maze after exposure to anoxia and re-oxygenation (learning experiment) showed a similar pattern to that observed before exposure (Fig. 5A). That is, there was a significant effect of individual trial number (two-way ANOVA, $F_{4,66}=6.323, P=0.0002$ ), but no effect of treatment group $\left(F_{1,66}=0.6773, P=0.4135\right)$ or any interaction $\left(F_{4,66}=0.7865\right.$, $P=0.5381$ ). The time to find food was significantly higher in individual trial 1 than in individual trial 3 (main effect of individual trial number, Tukey's multiple comparison test; $P=0.0238$ ), trial 4 $(P=0.0015)$ and trial $5(P=0.0012)$. The number of navigational errors (Fig. 5B) also tended to decrease with trial number (two-way ANOVA, $F_{4,80}=2.683, P=0.0373$ ), though multiple comparison tests failed to identify specific differences. There was no interaction $\left(F_{4,80}=0.4066, P=0.8034\right)$ and no effect of treatment group $\left(F_{1,80}=0.2823, P=0.5967\right)$.

Importantly, both normoxia- and anoxia-exposed fish were feeding after the exposure experiments, though feeding activity was slightly lower in post-anoxia fish (Fig. S6). On the first day of re-oxygenation, feeding was observed in all groups of normoxic fish and all the food was consumed, while $60 \%$ of the post-anoxic groups showed feeding activity and consumed $40 \%$ of the food.

\section{DISCUSSION}

Even if crucian carp are extraordinary in their ability to survive without oxygen for extended periods of time, and maintain brain function when anoxic, we here show that they do indeed suffer from moderate brain damage when exposed to anoxia and reoxygenation. We found that while the number of cells stained positive for TUNEL in the telencephalon of crucian carp did not increase with anoxia per se, the number of TUNEL-positive cells was increased by approximately threefold following $24 \mathrm{~h}$ of re- 

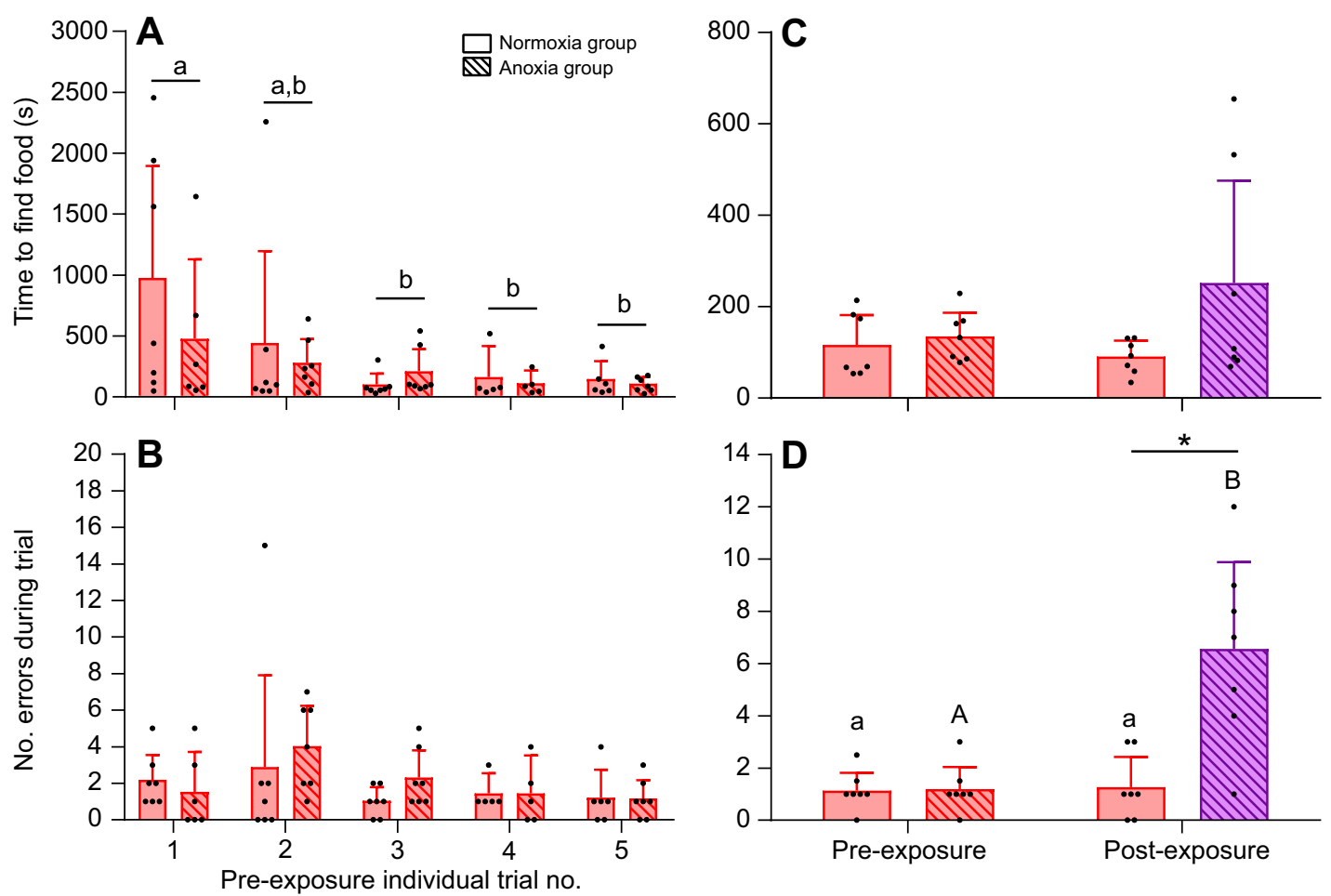

Fig. 4. Effect of anoxia and re-oxygenation on crucian carp memory. (A) Time taken to find food and (B) number of errors made in a maze in five consecutive trials before anoxia exposure (hatched bars) or control normoxia exposure for the normoxia group, and pre- and post-exposure comparison of (C) time taken to find food and (D) number of errors. The pre-exposure values in $C$ and $D$ are from the average of pre-exposure trials 4 and 5 before anoxia exposure (or control normoxia exposure for the normoxia group) and post-exposure values are from the trial carried out after 1 day of re-oxygenation after the anoxia exposure (or control normoxia for the normoxia group). Data are means $\pm 95 \% \mathrm{Cl}$ with individual values indicated by dots ( $n=7$ in each treatment). In A and $\mathrm{B}$ there was no effect of treatment; therefore, the difference between trials was assessed on the combined data and different letters indicate significantly different groups (main effect of individual trial number, Tukey's multiple comparison). In C and D, an asterisk indicates a significant difference between the normoxia group and the anoxia group within each time point, while lowercase and uppercase letters indicate a difference between pre-exposure and post-exposure for the normoxia and anoxia group, respectively (Sidak's multiple comparisons).

oxygenation. However, the increased cell death was not clearly associated with an up-regulation of the pro-apoptotic protease caspase 3. The protein expression of active caspase 3 was, nonetheless, elevated in some wild-caught individuals in May when oxygen levels were close to normoxic after several months of anoxia, and there seemed to be a marked effect of temperature on overall mRNA expression. At the whole-animal level we found that fish exposed to 7 days of anoxia and then $24 \mathrm{~h}$ of re-oxygenation exhibited impaired memory and reduced navigational accuracy in a maze with a food reward. However, the increase in cell death and associated behavioural impairment was transient. After 1 week of reoxygenation after anoxia exposure there was no longer any sign of increased cell death, and the number of proliferating cells was maintained while the PCNA mRNA expression was elevated. Moreover, the spatial learning ability was not impaired. Fish that had been exposed to anoxia learned to navigate a maze to a food reward at a similar rate to control normoxic fish. Combined, the results indicate that the crucian carp is able to repair any neurological damage sustained during anoxia and re-oxygenation.

\section{Brain damage}

We hypothesized that exposure to anoxia leads to increased cell death either during anoxia or during the following re-oxygenation. The fact that the number of dying brain cells in the telencephalon was highest during the first day of re-oxygenation indicates that the cell death we observed was more likely to have been induced by ROS, and not the lack of oxygen itself. It has previously been shown that the production of ROS increases during hypoxia and re-oxygenation, as a result of leakage from the electron transport chain, and that such an increase in ROS can induce cell death (Simon et al., 2000). Similar to the pattern observed in the present study, increased ROS and cell death has been shown to peak after $24 \mathrm{~h}$ of re-oxygenation in the rat brain (Coimbra-Costa et al., 2017). Intriguingly, in the present study there was considerable inter-individual variation in the number of TUNEL-positive cells, and some individuals appeared to sustain more brain damage than others. A similar variability was seen in the anoxia-re-oxygenation group in the memory experiment, and even in the wild-caught fish. The indication that crucian carp experience an increase in brain cell death that may be caused by increased ROS production contrasts with observations from anoxia-tolerant freshwater turtles, where ROS production is suppressed during anoxia and returns to normal during re-oxygenation (Pamenter et al., 2007). Furthermore, no indications of increased apoptotic activity have been observed in the turtle brain (Milton et al., 2007; Kesaraju et al., 2009; Larson et al., 2014). While crucian carp and freshwater turtles are often grouped together as prime examples of extreme anoxia tolerance, it is important to remember that they utilize markedly different strategies to achieve it. Freshwater turtles are close to comatose, and the spike and channel arrest and suppression of ATP demand probably aids in the protection of the brain. In contrast, the crucian carp brain remains functional and active, and it may therefore not protect itself as easily against tissue damage.

While there was a clear effect of anoxia and re-oxygenation on the prevalence of TUNEL-positive and hence dying cells, the effect of 

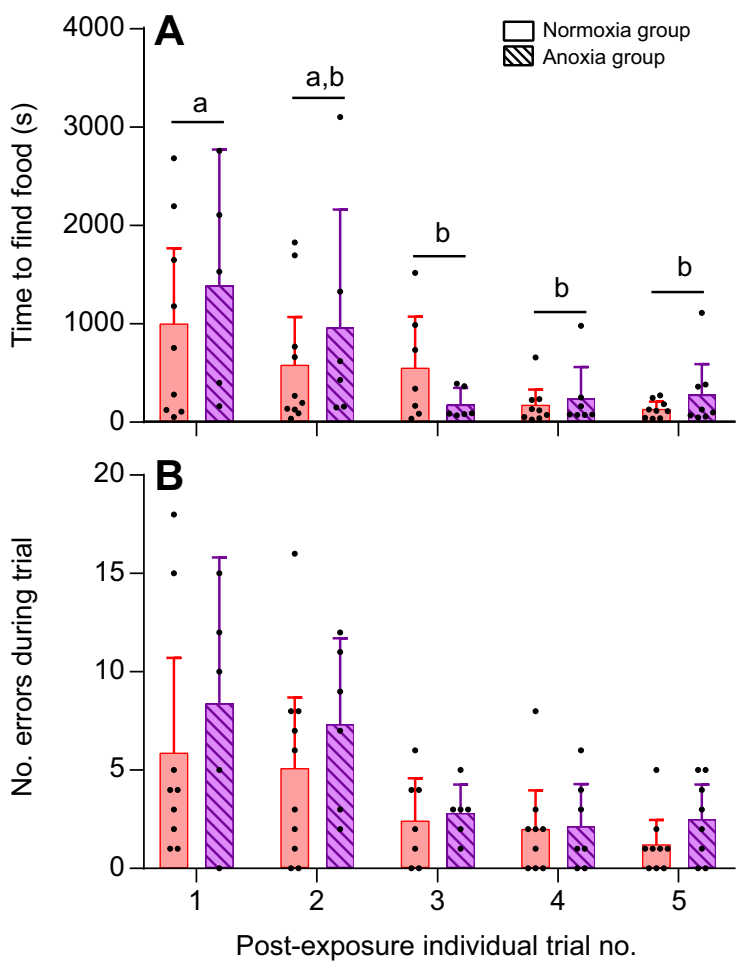

Fig. 5. Effect of anoxia and re-oxygenation on crucian carp learning ability. (A) Time taken to find food and (B) number of errors made in a maze in five consecutive individual trials with each fish $(n=10$ in the normoxia group and $n=8$ in the anoxia group, but note that not all fish completed all trials and the sample size therefore varies between trials) after anoxia exposure (or control normoxia exposure for the normoxia group). Note that the first trials were carried out after 8 days of normoxia following the 5 days of anoxia. Data are means $\pm 95 \% \mathrm{Cl}$ with individual values indicated by dots. As there was no effect of treatment in either measurement, the difference between trials was assessed on the combined data from the two groups, and hence different letters indicate a significant difference between trial numbers (main effect of trial number, Tukey's multiple comparison).

anoxia and re-oxygenation on caspase 3, a common executer enzyme in apoptosis, was less pronounced. The increase in wholebrain expression of caspase 3 mRNA was not concomitant with the increase in the number of TUNEL-positive cells at $24 \mathrm{~h}$ of reoxygenation. In addition, while the active (cleaved) form of the protein was present at $24 \mathrm{~h}$ of re-oxygenation, it was only weakly expressed and its expression was only marginally higher than that of control normoxic or anoxia-exposed fish. On the one hand, this could indicate that the observed cell death might have been caused by necrosis or caspase-independent apoptosis. While caspases have traditionally been viewed as key executers in the process of apoptosis, there are in fact caspase-independent pathways that can also lead to controlled forms of cell death (e.g. Kroemer and Martin, 2005). One such particular form of cell death is referred to as 'parthanatos', to distinguish it from apoptosis (David et al., 2009; Fatokun et al., 2014), while another is referred to as 'necroptosis' (Linkermann and Green, 2014), among many others (Berghe et al., 2014). Interestingly, recent studies have indicated that such caspaseindependent cell death can occur following DNA damage and oxidative stress (Ma et al., 2016; Wang et al., 2016), and that it might be important after more persistent ischaemic events (Manabat et al., 2003), which would be equivalent to the long-term anoxia that crucian carp tolerates. On the other hand, it should be kept in mind that the lack of a clear change in caspase 3 expression is not definite proof that caspase is not involved. Because caspase 3 is a complex enzyme, which is only active when cleaved into a smaller active and a larger non-active subunit, the cleaved active enzyme may be less stable, and there might be a high turnover which could make it more difficult to detect. It may also be that caspase 3 is activated in the earlier phase of re-oxygenation (e.g. Namura et al., 1998), though in a model of neonatal rat hypoxia-ischaemia, Zhu et al. (2000) found co-occurrence of TUNEL- and caspase 3-positive cells at $24 \mathrm{~h}$ reoxygenation. Another less likely explanation is that the cell death was only increased in certain areas of the brain (i.e. the telencephalon), and thus by analysing the whole brain any apparent differences in caspase 3 protein expression could have been obscured. However, as anoxia and re-oxygenation conditions would not have been restricted to a particular brain area, there is no reason to suspect that apoptosis would only occur in certain areas, unless the crucian carp is able to control which cells undergo apoptosis and which do not. Surprisingly, in a study on brain tissue from hypoxic/re-oxygenated mice, Chiu et al. (2012) actually found increased activity of caspase 1 in the amygdala, but not in the hippocampus, indicating that some differentiation might be possible, and so a more detailed examination of other areas of the crucian carp brain is clearly an important topic for future investigation.

Having assumed that anoxia/re-oxygenation-induced cell death would be a result of caspase 3-dependent apoptosis, rather than necrosis or caspase-independent apoptosis, we hypothesized that there would be signs of increased expression of caspase 3 in fish caught in the spring (May), during a time when oxygen levels had returned to normal after a long period of winter anoxia, and thus could have led to oxidative stress and ROS production that could induce caspase 3 activation. Indeed, there was a tendency for support of this hypothesis at the protein level, at least in some of the individuals. Caspase 3 mRNA levels were also significantly elevated in May compared with October and December. However, the elevation persisted during June to September, coinciding with both an increase in temperature from below $4^{\circ} \mathrm{C}$ to above $10^{\circ} \mathrm{C}$ and hyperoxic conditions. Additionally, feeding activity and hence dietary status would be much higher during the summer (e.g. Penttinen and Holopainen, 1992). Both elevated temperature and dietary status can be speculated to increase protein turnover, and maintaining protein abundance would therefore require a higher mRNA level, though more detailed experiments are obviously necessary to confirm such a hypothesis. As the change in expression was evident only at the mRNA level, and not at the level of active protein (of which abundance was actually maintained), it at least seems less likely to be indicative of an increase in apoptotic activity due to oxidative stress caused by the hyperoxic conditions in June and September. Furthermore, the blood oxygen partial pressure of crucian carp is likely to be low, as observed in the closely related goldfish (Carassius auratus; see Burggren, 1982), as a result of their high haemoglobin oxygen affinity. Moreover, under hyperoxic conditions the interlamellar cell mass has been reported to increase and hence has been proposed to serve as a barrier against oxygen entry (Tzaneva et al., 2011). Lushchak et al. (2005) actually found indications that short exposure to hyperoxia resulted in oxidative stress in goldfish tissues, though the level of hyperoxia used was much more severe (300\% air saturation) than observed in the present study (120-170\% air saturation). A similar observation has been made in mice (e.g. Terraneo et al., 2017). Still, it would be interesting to investigate whether hyperoxia itself can cause oxidative stress in crucian carp, even when not preceded by a long period of anoxia. 


\section{Regeneration}

Death of neurons in the mammalian brain is detrimental and generally irreparable, because of a very limited ability to produce new neurons, except for a few specialized areas such as the hippocampus (Nakatomi et al., 2002; Kokaia and Lindvall, 2003). Fish in general have more plastic brains, with a higher turnover of cells, and as their brain grows continually throughout their lifetime they are obviously able to produce new neurons (Clint and Zupanc, 2001; Zupanc, 2008; Ilieş et al., 2012). This plasticity is also indicated in the present data on crucian carp. The number of proliferating cells, contrary to the hypothesis, was not higher during re-oxygenation per se, but the number of proliferating cells was still higher than or equal to the number of TUNEL-positive cells, per investigated volume. As there were also signs of cell death in normoxic brains, the combined results would indicate that crucian carp have a natural turnover of cells in the brain, and that cell proliferation continuously replaces damaged cells, readily compensating for a transient increase in cell death caused by anoxia and re-oxygenation. A similar mechanism has been suggested to be utilized by hibernating frogs that sustain increased levels of cell death during hibernation as well as increased cell proliferation, whereby the number of functional cells is maintained (Cerri et al., 2009). However, as we only examined two time-points during re-oxygenation ( 1 and 7 days), it is also possible that an increase in post-anoxic cell proliferation was lagging behind, occurring later than 1 day, but having returned to normal levels before day 7 of re-oxygenation. The increased level of PCNA mRNA seen after 7 days of re-oxygenation, though it may seem like a long time, has been observed in a previous study on crucian carp (Sandvik et al., 2012), particularly in the heart, and could reflect that mRNA expression remains elevated longer than the protein itself.

\section{Memory and learning}

The finding of increased cell death, as hypothesized, seemed to also be reflected at the functional level. The anoxia-exposed crucian carp that had learned to find food in a maze prior to anoxia exposure made significantly more errors during the post-exposure trial compared with normoxic controls, even though they found the food equally quickly (except for two fish). There was an indication that feeding activity was slightly reduced following anoxia, but the fish included in the analyses of behavioural experiments all found the food, indicating that their appetite must have been sufficient to motivate them to navigate the maze. Also, one may have expected that fish lacking appetite would take longer to find the food, rather than finding it quickly and making more errors along the way. Arguably, entering dead-ends and turning back more frequently could be interpreted as the fish actively searching for the food. Nonetheless, crucian carp did not exhibit impaired spatial learning ability when given multiple days to recover in normoxic water, indicating that they are able to repair any brain damage caused by anoxia/re-oxygenation, and that this state was therefore transient. While comparable experiments to our knowledge are lacking for both other fish and anoxia-tolerant freshwater turtles, it is well established that memory is impaired in mammals suffering from brain ischaemia and reperfusion (Shih et al., 2013; Meng et al., 2014; Schimidt et al., 2014). However, the ability of mammals to regenerate neurons is limited and cognitive impairment in neonatal rats exposed to ischaemia and reperfusion is carried over into adulthood (Arteni et al., 2003). This contrasts with the transient effect observed in crucian carp, and the difference may to some extent rely on the general difference in plasticity and regenerative ability between mammals and fish. It is also likely that neural repair mechanisms are particularly well developed in the most anoxia-tolerant fish there is the crucian carp. It is important to note the individual variation, as the ability to navigate the maze after exposure to anoxia was clearly more impaired in some individuals than others, and that this variability fits well with the variability found in cell death.

\section{Perspectives and significance}

This study points to the conclusion that while crucian carp survive anoxia for extended periods of time, they are not fully able to protect themselves from the cellular insult that particularly the restoration of oxygen levels poses. While the fish show signs of increased cell death in the telencephalon, and signs that this could affect their brain function and behaviour, it is also evident that they can limit the amount of damage they sustain and recover from the insult, an ability that most other vertebrates lack. This makes the crucian carp an interesting model from a biomedical perspective - while it is unlikely that we will find ways to allow human tissues to survive severe anoxic insults without damage, it is feasible that studies on animals like the crucian carp can provide knowledge for how we can limit and repair the damage. Interestingly, we detected a large interindividual variation in the magnitude of effects, pointing to the possibility that natural selection may bring about the most anoxiatolerant crucian carp populations in habitats with the most severe anoxic periods. As far as we know, there have been no studies of population differences in anoxia tolerance in the species. Lastly, it is also important to bear in mind the protective role that low temperature might play during the winter in maintaining the damage at a level from which the fish can fully recover. Though the complexity and diversity in cell-death pathways certainly poses a challenge, future studies should attempt to more specifically identify the processes activated in the crucian carp brain during anoxia and particularly re-oxygenation, and how they may differ from the response of hypoxia-sensitive species.

\section{Acknowledgements}

The authors would like to thank Chris Wilson for assistance with the collection of fish.

\section{Competing interests}

The authors declare no competing or financial interests

\section{Author contributions}

Conceptualization: G.E.N., J.A.W.S., K.A.S., S.L.; Methodology: C.S., K.A.S., I.B.J., K.-O.S.; Formal analysis: S.L., J.A.W.S., L.Y.L., M.-K.T.; Investigation: S.L., J.A.W.S., M.-K.T., L.Y.L., C.S.C.; Resources: G.E.N.; Writing - original draft: S.L.; Writing review \& editing: S.L., J.A.W.S., M.-K.T., L.Y.L., C.S., I.B.J., K.-O.S., C.S.C., K.A.S., G.E.N.; Visualization: S.L., M.-K.T.; Supervision: S.L., J.A.W.S., C.S., I.B.J., G.E.N.; Project administration: G.E.N.; Funding acquisition: G.E.N., S.L., K.A.S.

\section{Funding}

The authors were financially supported by Carlsbergfondet [2012 010843 and 2013_01_0616 to S.L.], Norges forskningsråd [FRIMEDBIO 231260 to G.E.N., supporting S.L., J.A.W.S. and C.S.C.], the University of Oslo (M.-K.T., L.Y.L., K.-O.S.), and the Carnegie Trust for the Universities of Scotland (travel grant to K.A.S.).

\section{Data availability}

Sequences have been deposited in GenBank with accession numbers: MF288604, MF288605 and MF288603

\section{Supplementary information}

Supplementary information available online at

http://jeb.biologists.org/lookup/doi/10.1242/jeb.165118.supplemental

\section{References}

Ansari, B., Coates, P. J., Greenstein, B. D. and Hall, P. A. (1993). In situ endlabelling detects DNA strand breaks in apoptosis and other physiological and pathological states. J. Pathol. 170, 1-8.

Arteni, N. S., Salgueiro, J., Torres, I., Achaval, M. and Netto, C. A. (2003). Neonatal cerebral hypoxia-ischemia causes lateralized memory impairments in the adult rat. Brain Res. 973, 171-178. 
Berghe, T. V., Linkermann, A., Jouan-Lanhouet, S., Walczak, H. and Vandenabeele, P. (2014). Regulated necrosis: the expanding network of nonapoptotic cell death pathways. Nat. Rev. Mol. Cell Biol. 15, 135-147.

Buck, L. T. and Bickler, P. E. (1995). Role of adenosine in NMDA receptor modulation in the cerebral cortex of an anoxia-tolerant turtle (Chrysemys picta belli). J. Exp. Biol. 198, 1621-1628.

Buck, L. T. and Bickler, P. E. (1998). Adenosine and anoxia reduce N-methyl-Daspartate receptor open probability in turtle cerebrocortex. J. Exp. Biol. 201, 289-297.

Burggren, W. W. (1982). "Air gulping" improves blood oxygen transport during aquatic hypoxia in the goldfish Carassius auratus. Physiol. Zool. 55, 327-334.

Campo, M. L. (2009). Apoptosis. In Apoptosis: Involvement of oxidative stress and intracellular $\mathrm{Ca}^{2+}$ homeostasis (ed. G. Salido and J. Rosado), pp. 17-55. Dordrecht: Springer Netherlands.

Cerri, S., Bottiroli, G., Bottone, M. G., Barni, S. and Bernocchi, G. (2009). Cell proliferation and death in the brain of active and hibernating frogs. J. Anat. 215 124-131.

Charriaut-Marlangue, C. and Ben-Ari, Y. (1995). A cautionary note on the use of the TUNEL stain to determine apoptosis. Neuroreport 7, 61-64.

Chiu, G. S., Chatterjee, D., Darmody, P. T., Walsh, J. P., Meling, D. D., Johnson, R. W. and Freund, G. G. (2012). Hypoxia/reoxygenation impairs memory formation via adenosine-dependent activation of caspase 1. J. Neurosci. 32 , 13945-13955.

Clint, S. C. and Zupanc, G. K. H. (2001). Neuronal regeneration in the cerebellum of adult teleost fish, Apteronotus leptorhynchus: guidance of migrating young cells by radial glia. Dev. Brain Res. 130, 15-23.

Coimbra-Costa, D., Alva, N., Duran, M., Carbonell, T. and Rama, R. (2017). Oxidative stress and apoptosis after acute respiratory hypoxia and reoxygenation in rat brain. Redox. Biol. 12, 216-225.

David, K. K., Andrabi, S. A., Dawson, T. M. and Dawson, V. L. (2009) Parthanatos, a messenger of death. Front. Biosci. 14, 1116-1128.

Ellefsen, S., Stensløkken, K.-O., Sandvik, G. K., Kristensen, T. A. and Nilsson, G. E. (2008). Improved normalization of real-time reverse transcriptase polymerase chain reaction data using an external RNA control. Anal. Biochem. 376, 83-93.

Elmore, S. (2007). Apoptosis: a review of programmed cell death. Toxicol. Pathol. 35, 495-516.

Fagernes, C. E., Stensløkken, K.-O., Røhr, Å. K., Berenbrink, M., Ellefsen, S. and Nilsson, G. E. (2017). Extreme anoxia tolerance in crucian carp and goldfish through neofunctionalization of duplicated genes creating a new ethanolproducing pyruvate decarboxylase pathway. Sci. Rep. 7, 7884.

Farrell, A. P. T. and Stecyk, J. A. W. (2007). The heart as a working model to explore themes and strategies for anoxic survival in ectothermic vertebrates. Comp. Biochem. Phys. A 147, 300-312.

Fatokun, A. A., Dawson, V. L. and Dawson, T. M. (2014). Parthanatos: mitochondriallinked mechanisms and therapeutic opportunities. Brit. J. Pharmacol. 171, 2000-2016.

Fernandes, J. A., Lutz, P. L., Tannenbaum, A., Todorov, A. T., Liebovitch, L. and Vertes, R. (1997). Electroencephalogram activity in the anoxic turtle brain. Am. J. Physiol. 273, R911-R919.

Gavrieli, Y., Sherman, Y. and Ben-Sasson, S. A. (1992). Identification of programmed cell death in situ via specific labeling of nuclear DNA fragmentation. J. Cell Biol. 119, 493.

Girvan, J. R. and Braithwaite, V. A. (2000). Orientation behaviour in sticklebacks modified by experience or population specific? Behaviour 137, 833-843.

Granger, D. N. and Kvietys, P. R. (2015). Reperfusion injury and reactive oxygen species: the evolution of a concept. Redox Biol. 6, 524-551.

GrasI-Kraupp, B., Ruttkay-Nedecky, B., Koudelka, H., Bukowska, K., Bursch W. and Schulte-Hermann, R. (1995). In situ detection of fragmented DNA (TUNEL assay) fails to discriminate among apoptosis, necrosis, and autolytic cell death: a cautionary note. Hepatology 21, 1465-1468.

Green, D. R. and Reed, J. C. (1998). Mitochondria and apoptosis. Science 281, 1309-1312

Ho, F. Y., Tsang, W. P., Kong, S. K. and Kwok, T. T. (2006). The critical role of caspases activation in hypoxia/reoxygenation induced apoptosis. Biochem. Bioph. Res. Com. 345, 1131-1137.

Hogg, D. W., Pamenter, M. E., Dukoff, D. J. and Buck, L. T. (2015). Decreases in mitochondrial reactive oxygen species initiate $\mathrm{GABA}_{\mathrm{A}}$ receptor-mediated electrical suppression in anoxia-tolerant turtle neurons. J. Physiol. 593 2311-2326

Ilieş, I., Zupanc, M. M. and Zupanc, G. K. H. (2012). Proteome analysis reveals protein candidates involved in early stages of brain regeneration of teleost fish. Neuroscience 219, 302-313.

Johansson, D. and Nilsson, G. (1995). Roles of energy status, $K_{\text {ATP }}$ channels and channel arrest in fish brain $\mathrm{K}^{+}$gradient dissipation during anoxia. J. Exp. Biol. 198, 2575-2580.

Johnston, I. A. and Bernard, L. M. (1983). Utilization of the ethanol pathway in carp following exposure to anoxia. J. Exp. Biol. 104, 73-78.

Kesaraju, S., Schmidt-Kastner, R., Prentice, H. M. and Milton, S. L. (2009) Modulation of stress proteins and apoptotic regulators in the anoxia tolerant turtle brain. J. Neurochem. 109, 1413-1426.
Kokaia, Z. and Lindvall, O. (2003). Neurogenesis after ischaemic brain insults Curr. Opin. Neurobiol. 13, 127-132.

Koressaar, T. and Remm, M. (2007). Enhancements and modifications of prime design program Primer3. Bioinformatics 23, 1289-1291.

Kroemer, G. and Martin, S. J. (2005). Caspase-independent cell death. Nat. Med. 11, 725-730.

Larson, J., Drew, K. L., Folkow, L. P., Milton, S. L. and Park, T. J. (2014). No oxygen? No problem! Intrinsic brain tolerance to hypoxia in vertebrates. J. Exp. Biol. 217, 1024-1039.

Linkermann, A. and Green, D. R. (2014). Necroptosis. N. Engl. J. Med. 370 , 455-465.

Lipton, P. (1999). Ischemic cell death in brain neurons. Physiol. Rev. 79, 1431-1568.

Lushchak, V. I., Bagnyukova, T. V., Husak, V. V., Luzhna, L. I., Lushchak, O. V. and Storey, K. B. (2005). Hyperoxia results in transient oxidative stress and an adaptive response by antioxidant enzymes in goldfish tissues. Int. J. Biochem. Cell Biol. 37, 1670-1680.

Lutz, P. L. and Nilsson, G. E. (1997). Contrasting strategies for anoxic brain survival - glycolysis up or down. J. Exp. Biol. 200, 411-419.

Lutz, P. L., Nilsson, G. E. and Prentice, H. M. (2003). The Brain without Oxygen Causes of Failure - Physiological and Molecular Mechanisms for Survival. Dordrecht: Springer Netherlands.

Ma, D., Lu, B., Feng, C., Wang, C., Wang, Y., Luo, T., Feng, J., Jia, H., Chi, G., Luo, Y. et al. (2016). Deoxypodophyllotoxin triggers parthanatos in glioma cells via induction of excessive ROS. Cancer Lett. 371, 194-204

Manabat, C., Han, B. H., Wendland, M., Derugin, N., Fox, C. K., Choi, J., Holtzman, D. M., Ferriero, D. M. Vexler, Z. S. (2003). Reperfusion differentially induces caspase- 3 activation in ischemic core and penumbra after stroke in immature brain. Stroke 34, 207-213.

Meng, F., Wang, Y., Liu, R. U. I., Gao, M. E. I. and Du, G. (2014). Pinocembrin alleviates memory impairment in transient global cerebral ischemic rats. Exp. Ther. Med. 8, 1285-1290.

Milton, S. L., Nayak, G., Kesaraju, S., Kara, L. and Prentice, H. M. (2007) Suppression of reactive oxygen species production enhances neuronal survival in vitro and in vivo in the anoxia-tolerant turtle Trachemys scripta. J. Neurochem. 101, 993-1001.

Nakatomi, H., Kuriu, T., Okabe, S., Yamamoto, S.-I., Hatano, O., Kawahara, N. Tamura, A., Kirino, T. and Nakafuku, M. (2002). Regeneration of hippocampal pyramidal neurons after ischemic brain injury by recruitment of endogenous neural progenitors. Cell 110, 429-441.

Namura, S., Zhu, J., Fink, K., Endres, M., Srinivasan, A., Tomaselli, K. J., Yuan, J. and Moskowitz, M. A. (1998). Activation and cleavage of caspase-3 in apoptosis induced by experimental cerebral ischemia. J. Neurosci. 18, 3659.

Nayak, G. H., Prentice, H. M. and Milton, S. L. (2010). Neuroprotective signaling pathways are modulated by adenosine in the anoxia tolerant turtle. J. Cerebr Blood F. Met. 31, 467-475

Neumar, R. W. (2000). Molecular mechanisms of ischemic neuronal injury. Ann Emerg. Med. 36, 483-506.

Nilsson, G. E. (1989). Effects of anoxia on serotonin metabolism in crucian carp brain. J. Exp. Biol. 141, 419-428.

Nilsson, G. E. (1992). Evidence for a role of GABA in metabolic depression during anoxia in crucian carp (Carassius carassius). J. Exp. Biol. 164, 243-259.

Nilsson, G. E. (2001). Surviving anoxia with the brain turned on. Physiology 16 217-221

Nilsson, G. E. and Lutz, P. L. (1993). Role of GABA in hypoxia tolerance, metabolic depression and hibernation-possible links to neurotransmitter evolution. Comp. Biochem. Physiol. C 105, 329-336.

Nilsson, G. E. and Lutz, P. L. (2004). Anoxia tolerant brains. J. Cerebr. Blood F. Met. 24, 475-486

Nohl, H., Koltover, V., Stolze, K. and Esterbauer, H. (1993). Ischemia/reperfusion impairs mitochondrial energy conservation and triggers $\mathrm{O}_{2}$ - release as byproduct of respiration. Free Radical Res. Com. 18, 127-137.

Pamenter, M. E. (2014). Mitochondria: a multimodal hub of hypoxia tolerance. Can. J. Zool. 92, 569-589.

Pamenter, M. E., Richards, M. D. and Buck, L. T. (2007). Anoxia-induced changes in reactive oxygen species and cyclic nucleotides in the painted turtle. J. Comp. Physiol. B 177, 473-481.

Pamenter, M. E., Shin, D. S.-H. and Buck, L. T. (2008). AMPA receptors undergo channel arrest in the anoxic turtle cortex. Am. J. Physiol. 294, R606-R613.

Pamenter, M. E., Hogg, D. W., Ormond, J., Shin, D. S., Woodin, M. A. and Buck, L. T. (2011). Endogenous $\mathrm{GABA}_{\mathrm{A}}$ and $\mathrm{GABA}_{\mathrm{B}}$ receptor-mediated electrical suppression is critical to neuronal anoxia tolerance. Proc. Natl. Acad. Sci. USA 108, 11274-11279.

Penttinen, O.-P. and Holopainen, I. J. (1992). Seasonal feeding activity and ontogenetic dietary shifts in crucian carp, Carassius carassius. Environ. Biol. Fish 33, 215-221.

Perez-Pinzon, M. A., Rosenthal, M., Sick, T. J., Lutz, P. L., Pablo, J. and Mash, D. (1992). Downregulation of sodium channels during anoxia: a putative survival strategy of turtle brain. Am. J. Physiol. 262, R712-R715. 
Proskuryakov, S. Y. A., Konoplyannikov, A. G. and Gabai, V. L. (2003). Necrosis: a specific form of programmed cell death? Exp. Cell Res. 283, 1-16.

Rodríguez, F., López, J. C., Vargas, J. P., Broglio, C., Gómez, Y. and Salas, C. (2002). Spatial memory and hippocampal pallium through vertebrate evolution: insights from reptiles and teleost fish. Brain Res. Bull. 57, 499-503.

Rozen, S. and Skaletsky, H. (2000). Primer3 on the WWW for general users and for biologist programmers. Met. Mol. Biol. 132, 365-386.

Ruijter, J. M., Pfaffl, M. W., Zhao, S., Spiess, A. N., Boggy, G., Blom, J., Rutledge, R. G., Sisti, D., Lievens, A., De Preter, K. et al. (2013). Evaluation of qPCR curve analysis methods for reliable biomarker discovery: bias, resolution, precision, and implications. Methods 59, 32-46.

Sandvik, G. K., Tomter, A. B., Bergan, J., Zoppellaro, G., Barra, A.-L., Røhr, Å. K., Kolberg, M., Ellefsen, S., Andersson, K. K. and Nilsson, G. E. (2012) Studies of ribonucleotide reductase in crucian carp-an oxygen dependent enzyme in an anoxia tolerant vertebrate. PLOS ONE 7, e42784.

Santore, M. T., McClintock, D. S., Lee, V. Y., Budinger, G. R. S. and Chandel, N. S. (2002). Anoxia-induced apoptosis occurs through a mitochondriadependent pathway in lung epithelial cells. Am. J. Physiol. Lung C. 282 L727-L734

Schimidt, H. L., Vieira, A., Altermann, C., Martins, A., Sosa, P., Santos, F. W. Mello-Carpes, P. B., Izquierdo, I. and Carpes, F. P. (2014). Memory deficits and oxidative stress in cerebral ischemia-reperfusion: Neuroprotective role of physical exercise and green tea supplementation. Neurobiol. Learn. Mem. 114, 242-250.

Shih, P.-C., Yang, Y.-R. and Wang, R.-Y. (2013). Effects of exercise intensity on spatial memory performance and hippocampal synaptic plasticity in transient brain ischemic rats. PLOS ONE 8, e78163.

Simon, H.-U., Haj-Yehia, A. and Levi-Schaffer, F. (2000). Role of reactive oxygen species (ROS) in apoptosis induction. Apoptosis 5, 415-418.

Sloman, K. A. (2010). Exposure of ova to cortisol pre-fertilisation affects subsequent behaviour and physiology of brown trout. Horm. Behav. 58, 433-439.

Sollid, J. and Nilsson, G. E. (2006). Plasticity of respiratory structures-adaptive remodeling of fish gills induced by ambient oxygen and temperature. Resp. Physiol. Neurobiol. 154, 241-251.

Sollid, J., Kjernsli, A., De Angelis, P. M., Røhr, Å. K. and Nilsson, G. E. (2005). Cell proliferation and gill morphology in anoxic crucian carp. Am. J. Physiol. 289 R1196-R1201.

Stecyk, J. A. W., Stensløkken, K.-O., Farrell, A. P. and Nilsson, G. E. (2004). Maintained cardiac pumping in anoxic crucian carp. Science 306, 77.
Stensløkken, K.-O., Ellefsen, S., Vasieva, O., Fang, Y., Farrell, A. P., Olohan, L., Vaage, J., Nilsson, G. E. and Cossins, A. R. (2014). Life without oxygen: gene regulatory responses of the crucian carp (Carassius carassius) heart subjected to chronic anoxia. PLOS ONE 9, e109978.

Terraneo, L., Paroni, R., Bianciardi, P., Giallongo, T., Carelli, S., Gorio, A. and Samaja, M. (2017). Brain adaptation to hypoxia and hyperoxia in mice. Redox Biol. 11, 12-20.

Tzaneva, V., Bailey, S. and Perry, S. F. (2011). The interactive effects of hypoxemia, hyperoxia, and temperature on the gill morphology of goldfish (Carassius auratus). Am. J. Physiol. 300, R1344-R1351.

Untergasser, A., Cutcutache, I., Koressaar, T., Ye, J., Faircloth, B. C., Remm, M. and Rozen, S. G. (2012). Primer3-new capabilities and interfaces. Nucleic Acids Res. 40, e115

Vornanen, M., Stecyk, J. A. W. and Nilsson, G. E. (2009). The anoxia-tolerant crucian carp (Carassius carassius L.). In Hypoxia, Vol. 27 (ed. G. R. Jeffrey, A. P. Farrel and C. Brauner), pp. 397-441. Cambridge, MA, USA: Academic Press.

Vornanen, M., Asikainen, J. and Haverinen, J. (2011). Body mass dependence of glycogen stores in the anoxia-tolerant crucian carp (Carassius carassius L.). Naturwissenschaften 98, 225-232.

Wang, Y., An, R., Umanah, G. K., Park, H., Nambiar, K., Eacker, S. M., Kim, B., Bao, L., Harraz, M. M., Chang, C. et al. (2016). A nuclease that mediates cell death induced by DNA damage and poly(ADP-ribose) polymerase-1. Science 354.

White, B. C., Sullivan, J. M., DeGracia, D. J., O’Neil, B. J., Neumar, R. W., Grossman, L. I., Rafols, J. A. and Krause, G. S. (2000). Brain ischemia and reperfusion: molecular mechanisms of neuronal injury. J. Neurol. Sci. 179, 1-33.

Zhang, T., Zhang, Y., Cui, M., Jin, L., Wang, Y., Lv, F., Liu, Y., Zheng, W., Shang, H., Zhang, J. et al. (2016). CaMKII is a RIP3 substrate mediating ischemia- and oxidative stress-induced myocardial necroptosis. Nat. Med. 22, 175-182.

Zhao, H., Jaffer, T., Eguchi, S., Wang, Z., Linkermann, A. and Ma, D. (2015). Role of necroptosis in the pathogenesis of solid organ injury. Cell Death Dis. 6, e1975.

Zhu, C., Wang, X., Hagberg, H. and Blomgren, K. (2000). Correlation between caspase- 3 activation and three different markers of DNA damage in neonatal cerebral hypoxia-ischemia. J. Neurochem. 75, 819-829.

Zhu, C., Qiu, L., Wang, X., Hallin, U., Candé, C., Kroemer, G., Hagberg, H. and Blomgren, K. (2003). Involvement of apoptosis-inducing factor in neuronal death after hypoxia-ischemia in the neonatal rat brain. J. Neurochem. 86, 306-317.

Zupanc, G. K. H. (2008). Adult neurogenesis and neuronal regeneration in the brain of teleost fish. J. Physiol. 102, 357-373. 